\title{
Does Corporate Governance Influence Earnings Management in Latin American Markets?
}

\author{
Jesus Sáenz González • Emma García-Meca
}

Received: 7 May 2012/ Accepted: 27 March 2013/Published online: 26 April 2013

(c) The Author(s) 2013. This article is published with open access at Springerlink.com

\begin{abstract}
Although US and European research has documented improvement in earnings quality associated with corporate governance characteristics, the situation in Latin America is questionable, given the business environment in which firms operate, which is characterized by controlling family ownership and weak legal protection. The purpose of this study is to examine the relation between the internal mechanisms of Corporate Governance and Earnings Management measured by discretionary accrual. We use a sample of listed Latin American non-financial companies from the period 2006-2009. Our results show how in the Latin American context the role of external directors is limited and that Boards which meet more frequently take a more active position in the monitoring of insiders, so showing a lower use of manipulative practices. In addition, we find a non-linear relation between insider ownership and discretionary accruals, also pointing to the fact that ownership concentration may be a manipulative practices constrictor mechanism only when the ownership of main shareholders is moderate. The findings have important policy implications since this is, to the best of our knowledge, the first study to analyze the relation between the effectiveness of the government and the earnings management behavior. As policy implications, we document how when a country implements controls aimed at
\end{abstract}

\section{J. Sáenz González}

Accounting and Finance Department, Universidad Autónoma de Ciudad Juárez, Ciudad Juárez, Mexico

e-mail: saenz7305@hotmail.com

E. García-Meca $(\bowtie)$

Accounting and Finance Department, Business Faculty,

Technical University of Cartagena, c/Real 3,

30201 Cartagena, Spain

e-mail: emma.garcia@upct.es reducing corruption, strengthening the rule of law or improving the effectiveness of government, this leads to a reduction in firm earnings management.

Keywords Board of Directors - Corporate governance . Corruption - Discretionary accruals · Ownership structure

\section{Introduction}

In recent years large accounting fraud uncovered in the stock markets has once again confirmed the existence of ethical failures and the importance of transparency and reliability of the financial information provided to markets (Lang and Lundholm 2000). The regulatory response to financial scandals has been to take measures to protect information transparency, mitigate conflicts of interest and ensure the independence of auditors, all in order to protect the investors interests' and increase the confidence of capital markets (Leuz et al. 2003). A weak governance structure may provide an opportunity for managers to engage in behavior that would eventually result in a lower quality of reported earnings, which is a strong indication of a serious decay in business ethics.

Since the studies published by Jensen and Meckling (1976) and Fama and Jensen (1983), it has been assumed that both, the role of the board of directors and ownership structure, are crucial in monitoring managerial activity, as they are capable of reducing agency costs resulting from the alignment of ownership and management interests. Thus, several studies document a significant relation between the characteristics of the board of directors and the integrity of accounting information (Rahman and Ali 2006; Patelli and Prencipe 2007; Hashim and Devi 2008). Some other studies analyze the effect of the internal ownership 
and shareholding concentration held by major shareholders on the quality of financial results (Lefort 2005; Kim and Yi 2006; Price et al. 2006). All these studies relate mainly to Anglo-Saxon countries, where outside investors are wellprotected by the legal system (e.g., United States, United Kingdom), the level of transparency is high and most listed firm' present widely held ownership structures.

The above scenarios cannot be readily applied, however, to the case of Latin America and many other countries characterized by weak legal protection of minority shareholders' interests and concentrated ownership structures. In the Latin American context, the ownership structure of listed firms is characterized by high levels of concentrated ownership where many firms are directly controlled by one of the industrial or financial conglomerates that operate in the region (Lopez and Saona 2005; Cespedes et al. 2008), through the use of pyramidal structures that enable controlling shareholders to separate their voting and cash flow rights (Mendes and Mazzer 2005), and by the notable presence of family groups among such owners (La Porta et al. 1999; Castañeda 2000a, b; Rabelo and Coutinho 2001; Santiago et al. 2009). Moreover, the control exerted by these family owners is not usually limited solely to their participation in the firms' ownership since they usually play an active role in management (La Porta et al. 1999). Additionally, Boards of Directors in Latin American firms are not as independent as those in developed countries, making them less effective in monitoring the decisions taken by managers (Santiago and Baek 2003; Lefort 2005; Helland and Sykuta 2005).

According to the approaches set out, this paper's main objective is to analyze the relation between the internal mechanisms of $\mathrm{CG}$ and $\mathrm{EM}$ in firms listed on the main Latin American stock markets, specifically, on the markets of Argentina, Brazil, Chile, and Mexico, during the period 2006-2009. These countries have not been strangers to the initiatives of practically all Western countries since the promulgation in 2000 of the Sarbanes-Oxley in the U.S. and it seems appropriate to verify empirically the effects of CG mechanisms such as ownership structure and board of directors in these countries. Therefore, another objective of this paper is to analyze the relation between board and earnings management in this type of context, where both the predominant agency conflict and the institutional environment differ from those in the Anglo-Saxon and Continental European markets.

The specific characteristics of Latin American countries make it also interesting to analyze the country governability level, because corruption is prevalent in emerging countries, affecting the effective function of governments and economies (Gill and Kharas 2007; Aidt 2009). The implementation of controls aimed at reducing corruption, to strengthen the rule of law or to improve the effectiveness of the government in a country could lead to a reduction in opportunistic behavior and, consequently, could reduce the earnings management practices in firms. Thus, by using a government index proposed by the previous literature we will test if those countries that control corruption have a stronger rule of law and higher effectiveness of their government reduce the earnings management behavior. This study contributes to the growing body of literature related to $\mathrm{CG}$ in the following ways. First, it extends the very limited research on the relation between CG and EM in Latin America and provides a more comprehensive picture of this association. Second, it provides further evidence by analyzing the empirical evidence in a Latin American context, where the Boards of Directors, legal investors' protection, the presence of reference investors and the threat of corporate takeover differs substantially from other regions of the world, especially in those countries with developed markets. Third, our study extends the literature to ethical aspects that are scarce and have not been tested yet in the relation between the internal mechanisms of CG and EM in Latin America, such as corruption, rule of law, and government effectiveness.

The remainder of the paper is organized as follows: in next section, the study hypotheses are developed; in third section, we present the design and research methodology; in fourth section, we show the statistical results; in fifth section, we discuss the results, the limitations, and future lines of research and; finally, in last section we present the main conclusions of our study.

\section{Previous Literature and Development of Hypotheses}

\section{Ownership Structure}

Ownership structure is an internal control mechanism that focuses on the aspects that define the ownership of the company and refers to the manner in which titles or rights of representation redistribute the capital of the company in one or more individuals or legal entities. The monitoring power derived from the ownership structure results in a kind of control exercised over the company and, particularly, over the top management team.

Previous studies mainly focus on the effect of insider ownership on the EM (Sanchez-Ballesta and Garcia-Meca 2007; Teshima and Shuto 2008), along with ownership concentration (measured by the fraction of ownership held by major shareholders or by the proportion of ownership held by the main shareholders of the firm) (De Miguel et al. 2004; Boubraki et al. 2005). However, Demsetz and Villalonga (2001) affirm that in order to treat ownership structure appropriately and to account for the complexity of interest represented in a given ownership structure, different 
dimensions of ownership structure must be considered. Following this suggestion, we analyze apart from these two common dimensions examined by previous literature, two different dimensions of ownership structure that the literature has also shown could be an effective CG mechanism in monitoring management decisions, able to constrict manipulative practices and, consequently, improve earnings quality: family ownership (Wang 2006; Ali et al. 2007; Bona et al. 2008) and institutional ownership (Ferreira and Matos 2008; Ruiz et al. 2009; Ferreira et al. 2010). The next sections describe the development of the hypotheses related to the four ownership structure variables examined in our study.

\section{Internal Ownership}

Agency Theory suggests that when managers are not owners of the entity that they lead or they have a low equity stake in it, their behavior is affected by self-interest that is far from goals of maximizing corporate value and, therefore, from the interest of shareholders, and this facilitates EM (Jensen and Meckling 1976; Fama 1980; Fama and Jensen 1983; Healy 1985; Holthausen et al. 1995). In contrast, if managers have a certain proportion of their wealth materialized in shares of the company that they lead, or their personal wealth directly depends on the decisions taken will tend to align, to a greater extent, their interests with other shareholders (convergence of interests' hypothesis) and show less discretionary behavior (Mehran 1995; Alonso and De Andrés 2002). Thus, insider ownership can be seen as a way to constrain the opportunistic behavior of managers, so the level of discretionary accruals is predicted to be negatively associated to insider ownership (Wartfield et al. 1995). However, excessive internal ownership may also have an adverse effect on the company, because the higher power of the managers could lead them to take accounting decisions that reflect personal reasons, so affecting the goal of maximizing the value of the company (Yermack 1997; Aboody and Kaznik 2000). Machuga and Teitel (2009) analyze earnings quality surrounding the implementation of Code of Best Corporate Practices for a sample of Mexican listed companies, and find that firms with internal ownership show a greater earnings quality compared to those that do not have managerial ownership.

Therefore, the argument that insider ownership constrains the opportunistic interest of managers suggests a negative relation between the proportion of shares held by insiders and the absolute value of discretionary accruals. We address this view by testing the following hypothesis:

H1 Insider shareholding negatively affects earnings management.

\section{Ownership Concentration}

Large shareholders play a key role in internal control of companies, because the volume of participation encourages them to monitor and influence the strategy of the firm in which they have invested (Fernandez 1998; Yeo et al. 2002; Gabrielsen et al. 2002). This means that a greater ownership concentration should, according to the efficient monitoring hypothesis (Jensen and Meckling 1976), lead to a less opportunistic behavior and a greater tendency to maximization the value of the firm (Fama 1980; Fama and Jensen 1983), having a positive impact on the informativeness of accounting earnings, since increasing the participation of the controlling shareholder reduces the incentives of this owner to expropriate the wealth of minority shareholders (De Miguel et al. 2004; Boubraki et al. 2005). In this sense, De Bos and Donker (2004) point out that increased ownership is an effective CG mechanism in monitoring accounting decisions taken by management and implies a higher earnings quality.

Yeo et al. (2002) deal with the monitoring role played by external unrelated block holders, which reduces the opportunities of earnings management, and de Bos and Donker (2004) also show that increased ownership concentration is an effective corporate governance mechanism in monitoring accounting decisions of incumbent management, such as voluntary accounting changes. However, when the level of ownership concentration is too high it can lead to agency problems due to the expropriation of the minority shareholders' interests (Boubraki et al. 2005; Lefort 2007). In this paper we support the efficient monitoring hypothesis and suggest a negative association between ownership concentration and earnings management:

H2 Ownership concentration negatively affects earnings management.

\section{Family Ownership}

Several studies have shown how certain distinctive characteristics of family firms have a positive impact on corporate behavior. Anderson and Reeb (2003) suggest that the long-term ties typical of the family owner mean that external agents, such as suppliers or lenders, develop their business with the controlling family over a long period of time. This leads to these external agents perceiving a "family reputation" that has economic consequences that last not only for the owners' lifetime, but throughout the lives of his/her heirs. In the same line, Wang (2006) and Ali et al. (2007) states that long-term orientation and reputation concerns means that family firms do not act opportunistically in reporting earnings, such that their actions are more in line with a short-term orientation. 
At this point, it could be concluded that, compared with non-family firms, controlling family firms would tend to maximize the firm's wealth in the long term. Thus, there would be fewer incentives to obtain private benefits at the expense of minority shareholders, which in turn could result in a higher earnings quality (Bona et al. 2008). However, Wang (2006) and Ali et al. (2007) also point out that one of the main limitations of their studies is the difficulty in extending their results to other settings where there is a lower protection of minority shareholders, and consequently, more concentrated ownership structures, such as Latin America. This is because the presence of concentrated ownership structures and the presence of family groups may trigger other problems of CG. In this sense, when there are large shareholders in firms there is more likelihood of conflicts arising from interests between these parties and the minority shareholders. In family firms, given their greater information asymmetries, the likelihood of expropriation of corporate resources is high, including the likelihood of entrenchment of an unskilled family management team (Mcvey and Draho 2005; Sacristan and Gomez 2007).

According to this argument, Castrillo and San Martín (2007) study the relation between ownership structure and the Board of Directors with managerial discretion for a sample of Mexican companies, and find that family ownership and the level of corporate leverage explain the degree of discretion that managers have for manipulating accounting numbers in Mexico. Other studies on the Latin American context, such as Castañeda (2000a, b) and Rabelo and Coutinho (2001) show that a high family participation exerts a decisive influence on the control of companies, where the owners are usually issued non-voting shares and develop pyramidal ownership structures to obtain funds without dispersing their capacity to control the companies. According to previous arguments, it could be argued that the greater concentration of voting rights could entail greater incentives for controlling shareholders to obtain private benefits, i.e., increasing EM (Bona et al. 2008).

Therefore, the argument that high levels of family ownership can lead to agency problems due to the expropriation of the minority shareholders' interests in Latin America, suggests a positive influence on earnings management:

H3 Family ownership positively affects earnings management.

\section{Institutional Ownership}

Institutional investors plays an active role in controlling managerial discretion and improving the efficiency of information in capital markets, as the investors are sophisticated with advantages in acquiring and processing information (Balsam et al. 2003; Koh 2003; Ferreira and Matos 2008; Ruiz et al. 2009; Ferreira et al. 2010), so limiting opportunism and promoting the reduction of agency costs (Shleifer and Vishny 1997; Rajgopal et al. 2002; Chung et al. 2002). In this way, Koh (2003) and Hsu and Koh (2005) propose that the role of institutional investors in firms can be approximated by considering the level of participation of the institutional shareholders in them, i.e., that institutional ownership may act as a governance mechanism that affects the EM based on the level of their participation. Specifically, low levels of investor participation are assimilated to temporary or short-term views, whereas when the level of participation increases, the institutional investor is assimilated to an investor more engaged with the company, and hence, involved in the resolution of conflicts that may arise therein.

In Latin America, Lefort (2005) points out that institutional investors have an important role in CG of companies. The early reform of the pension funds in Chile, followed later by Argentina, Colombia, Peru, and Mexico, gave institutional investors an important role as providers of capital and prompted several changes to the laws of capital markets in the region; it helped to substantially improve the protection of minority shareholders (Iglesias 2000), given the nature of funds administered and their political influence.

Therefore, the argument that a higher institutional ownership should lead to a positive impact on corporate behavior, because the managers would be discouraged to make EM due to the pressure from institutional investors to focus in long term, suggests a negative relation between the proportion of shares held by institutional owners in Latin America and the absolute value of discretionary accruals.

H4 Institutional investors negatively affect earnings management.

\section{Board of Directors}

The Board of Directors is the governance body to which shareholders delegate the responsibility of overseeing, compensating and substituting managers, as well as approving major strategic projects. It therefore plays a key role in the overall overseeing of the company and the monitoring of top management in particular (Jensen and Meckling 1976; John and Senbet 1998; Daily et al. 2003; Chatterjee et al. 2003). Thus, the Board of Directors is an essential element of CG and is considered the main internal mechanism in reducing agency conflicts, either between managers and shareholders or between majority and minority shareholders (LaFond and Roychowdhury 2006; De Andrade et al. 2009). 
The CG literature shows different characteristics that may influence the effectiveness with which the Boards monitor the performance of managers in firms (John and Senbet 1998; Rahman and Ali 2006). However, according to Fernandez et al. (1997), most of the previous CG literature discusses mainly two characteristics or variables that influence the monitoring capabilities of Boards: their independence and size. As well as these two characteristics, we analyze its activity and the CEO duality or concentration of power. The next sections describe the development of the hypotheses related to the four Board characteristics examined in our study.

\section{Board Size}

Studies such as Davila and Watkins (2009) in Mexico and Ferraz et al. (2011) in Brazil, find that if the size of the Board is very small, the monitoring of the management team is smaller too, so they tend towards greater discretion in receiving higher remuneration, a greater chance of EM and are more prone to information asymmetry (Fernandez 1998; Azofra et al. 2005; Brick et al. 2006). Thus, a larger size of Board assumes a better supervision of the management team and a higher quality of corporate decisions (Pearce and Zahra 1992). In this sense, Chin et al. (2006) for a sample of 313 firms from Hong Kong, found a negative relation between the size of the Board and EM, concluding that a larger Board fewer are the manipulative practices made by the management of companies.

However, excessive size can be an obstacle for quick and efficient decision-making, due to problems of coordination and communication. Santiago and Brown (2009) take a sample of 97 companies in Brazil, Chile, and Mexico and find a positive relation between the size of the Board and EM. This indicates that the low separation between ownership and control that exists in Latin American companies assumes that with a larger size of Board the levels of monitoring of the management team decrease, so increasing the risk of expropriation by controlling shareholders and the propensity to the discretion of the board members to establish a higher level of remuneration and manipulate the results of companies for their own benefit (Fernandez et al. 1997; Core et al. 1999; Thomsen 2008). We support this last view and pose the following hypothesis:

H5 Board Size positively affects earnings management.

\section{Board Independence}

Because previous CG literature shows that independence is often considered as a substitute for transparency and disclosure of annual reports, it has often recommended that the number of external members in board of directors be greater than the owners, for there to be more oversight of management and to maximize the value of the organization (Zattoni and Cuomo 2010; Ferraz et al. 2011). This suggests that the degree of Board independence is directly related to the quality of information that firms issues (Cheng and Courtenay 2006). Also, CG literature has affirmed that a greater degree of Board independence provides more control over the development of company activities and a better defence of the issue of information as a mechanism to carry out processes of accountability to different groups of business interest, because the external directors are not linked to the management of the entity (Willekens et al. 2005; Karamanou and Vafeas 2005; Cheng and Courtenay 2006). Therefore, Board independence seeks fairness in the strategic decisions taken by the Board and effective monitoring of the decisions and activities of managers, thus ensuring transparency of information and proper image on the outside of organizations (Chen and Jaggi 2000; Patelli and Prencipe 2007). Furthermore, several studies provide empirical evidence relating to the role of external directors on the constriction of EM, documenting that a higher proportion of external directors, will mean greater and better quality of financial information issued by firms, so reducing the chances of EM (Xie et al. 2003; Davidson et al. 2005; García Osma and Gill de Albornoz 2007; Bradbury et al. 2006; Jaggi et al. 2009).

Most recent studies such as Price et al. (2006, 2007), Teitel and Machuga (2008), Chong et al. (2009), Davila and Watkins (2009), and Ferraz et al. (2011) show that a legal framework in capital markets (such a Code of Best Corporate Practices) has forced Latin American firms to include more external directors, so making it possible to improve the way that firms disclose their financial information, and they therefore show a greater transparency in their reports and decrease the chances of EM. From the above, we formulate the following hypothesis in the sense that a possible negative association could be expected between the degree of Board independence and EM.

H6 The Boards independence affects negatively on earnings management.

\section{Board Activity}

Another characteristic related to the Board of Directors is its activity, measured by the number of meetings, since its size and independence are necessary but not sufficient. Thus, Adams (2003) and Garcia Lara et al. (2009) suggest that the number of meetings is a good proxy for the directors' monitoring effort. As Menon and Williams (1994) notes that Boards that do not meet, or meet only a few times, are unlikely to be effective monitors. In this 
way, Eguidazu (1999) argues that it is also essential that the Boards be active and understand their task as a continuous process, and Vafeas (1999) has demonstrated empirically the existence of a direct relation between the Board activity and the profitability of the firm. In consequence, it is possible that Boards that are more engaged in their duties take a more active stance in order to safeguard the quality of accounting information, so, in principle, a negative relation between the Board's activity and EM is to be expected (Monterrey and Sánchez 2008). An opposing view is that Board meetings are not necessarily useful because routine tasks absorb much of the limited time that directors and CEO's spend together to set the agenda for Board meetings (Lorca et al. 2011). Based on the above, we formulate the following hypothesis in the sense that a negative association between the Boards activity and EM could be expected.

H7 A greater number of Board meetings influences earnings management negatively.

\section{CEO Duality}

It is understood that there is concentration of power in a company when the same person takes the role of chief executive and president of the Board. Some empirical studies developed in Latin America show that in practice this separation is not fulfilled, despite the recommendations of the Codes of Good Governance. There is a high concentration of ownership and control held by families that produces an effect of entrenchment by the chairman of Board of Directors when he maintains family ties with the major shareholders. In this sense, in Mexico, Castañeda (2000b) found that in $85 \%$ of Mexican companies listed on the Stock Exchange in New York the majority owners preside the Board of Directors and also exert the role of CEO. However, Husted and Serrano (2002) argues that while in Mexican firms, the family retained both functions, a group of them showed that the majority owner delegated the role of general manager to a family member, which responds to succession process and the need to provide a resource management for the business trust (Hoshino 2004; Ruiz-Porras and Steinwascher 2007).

Also, Leal and Carvalhal da Silva (2005) in Brazil, through the application of surveys on a sample of 400 listed companies, documented that $36 \%$ of companies have power concentrated in the same person. In Argentina, Chisari and Ferro (2009) for a sample of 100 listed firms, find that in $75 \%$ of the corporations the chairman and CEO are the same person. This situation is not very different in Chile; Lefort and Walker (2005) obtain similar results in a sample of 120 listed companies, pointing out that only in $21 \%$ of corporations is the Chairman of the Board independent, that is, there is no duplication of functions between President-CEO, a situation that is widespread throughout Latin America. Based on the above, we formulate the following hypothesis in the sense that a positive association between CEO duality and EM could be expected.

H8 The existence of concentration of power (CEO duality) increases earnings management.

\section{Government Index}

While corruption is prevalent in emerging countries, there is increasing focus on the degree of its predictability to affect the effective functioning of governments and economies (Gill and Kharas 2007; Aidt 2009). Voliotis (2011) look at different forms of organisational corruption in the European Union; Galang's (2011) study reviews the corruption literature in leading management journals while Dela Rama (2011) looks at how the CG of family-owned business groups, deals with different forms of corruption in Asia. However, literature regarding ethical aspects on Latin American countries is scarce and the effects on discretional behavior have not been tested yet.

Thus, we use the Government Index (GOV_Index) taken from the research project "Worldwide Governance Indicators" (WGI) ${ }^{1}$ proposed by Kaufmann et al. (2010) and published by the world Bank $^{2}$ between the periods 2006-2009. We integrate this index using three main indicators that previous literature has shown as very important factors in measuring the way in which the governability of a country helps to reduce or increase opportunistic behavior in firms: control of corruption, rule of law, and government effectiveness (Aidt 2009; Voliotis 2011; Galang 2011). Low levels of governability (a low index value) imply, generally, behaviors that affect the trust placed in public officials and, therefore, undermine the basis of government trust (Shleifer and Vishny 1993). The presence of corruption, the lack of confidence, and respect of the agents in the quality of contract enforcement, property rights, courts, as well as the ineffectiveness of governments in the implementation and formulation of policies, increase the risks of the entrepreneur, because people from outside the value chain may have opportunistic behavior and take advantage of their profits, a

\footnotetext{
1 This indicator reflects the traditions and institutions over which the authority in a country is exercised, including the process by which governments are selected, monitored and replaced, the government's ability to formulate and implement effective policies, and respect of citizens and the status of the institutions that govern their economic and social interactions. The governance indicators cover 213 countries and are based on 33 sources that include a collection of more than 120,000 responses from citizens, experts, and companies from around the world (Kaufmann et al. 2010).

2 Available at www.worldbank.org.
} 
situation that is feasible due to the relatively high levels of asymmetry information that characterize the economic activity (Anokhin and Schulze 2008). In addition, corruption, inefficiency of governments and a weak rule of law as well as other weaknesses in the country infrastructure, increase transaction and agency costs, thus limiting the income of the firms (Manzetti and Wilson 2007) and, in consequence, increase the opportunistic behavior of firms. By contrast, control of corruption, a strong rule of law and an effectiveness of government (a high index value) increase the chance of entrepreneurs capturing a larger portion of the revenues that they generate by increasing the reliability of cash flows (Rose-Ackerman 2001) and, consequently, they reduce the opportunistic behavior in firms. Furthermore, in recent years Latin American countries have made reforms to their legal frameworks, modifying laws and establishing harsher punishments for those persons who demonstrate corruption practices. Based on the above, we formulate the following hypothesis in the sense that a negative association between the government index and EM could be expected.

H9 A country with higher levels of governability shows a lower level on earnings management practices.

\section{Design and Research Methodology}

Sample and Data

Our sample comprises firms listed on main Latin American stock markets, specifically, in the markets of Argentina, Brazil, Chile, and Mexico, during the period 2006-2009. We select these countries for their relevance in the Latin America Economy and discard Colombia due to the insufficient number of available observations. The sample is obtained from companies listed on the Mexican Stock Exchange (Bolsa Mexicana de Valores), Santiago Stock Exchange (Bolsa de Comercio de Santiago), Stock Market of Buenos Aires (Mercado de Valores de Buenos Aires), and the Sao Paulo Stock Exchange (Bolsa de Valores de Sao Paulo) during the period 2006-2009. Financial institutions are excluded, as is common in this type of studies because of their particular accounting practices. The accounting data on financial statements was obtained from Economatica database, while data on CG and ownership structure come directly from annual reports submitted by companies to the different regulatory agencies, ${ }^{3}$ which are available on their websites. We obtained information for 435 firms and a total of 1,740 observations for the period from 2006 to 2009 . The composition of the sample allows

\footnotetext{
${ }^{3}$ For Mexico, Brazil, Chile, and Argentina the annual reports are available at www.bmv.com.mx; www.bmfbovespa.com.br; www. bolsadesantiago.com; www.cnv.gov.ar.
}

the combination of time series and cross sections with adequate opportunity to take advantage of the creation of a panel data, especially in the control of unobserved heterogeneity, i.e., the individual characteristics of each entity that are not observable but affect the variables under study (Arellano and Bover 1991; Arellano 1993; Himmelberg et al. 1999; Palia 2001; Brick et al. 2005). Additionally, since at present the idea of using unbalanced panels with total observations is widely accepted, the option of analyzing balanced panels with fewer companies is discarded because it may be conditioned by the survival bias (Baltagi and Chang 1994).

\section{Measurement of Abnormal Accruals}

We define earnings management in terms of 'absence of manipulative practices'. This is because the intentional manipulation of earnings by managers may reduce the usefulness of earnings to the overall users (Velury and Jenkins 2006; Matis et al. 2010). Earnings that are persistence and predictable may not be of high quality if this results from earnings management (Dechow and Schrand 2004). We use the modified version of Jones (1991) proposed by Dechow et al. (1995) which has been used in other studies such as Teoh et al. (1998) and Xie et al. (2003) to determine the discretional accruals. Following Dechow et al. (1995), we compute the accrual component of earnings as:

$$
\begin{aligned}
\text { Total Accruals } & =\left(\Delta \mathrm{CA}_{i t}-\Delta \mathrm{Cash}_{i t}\right)-\left(\Delta \mathrm{CL}_{i t}\right. \\
& \left.-\Delta \mathrm{STD}_{i t}\right)-\mathrm{Dep}_{i t}
\end{aligned}
$$

where $\Delta \mathrm{CA}_{i t}=$ change in total current assets; $\Delta$ Cash $_{i t}=$ change in cash and cash equivalents; $\Delta \mathrm{CL}_{i t}=$ change in total current liabilities; $\Delta \mathrm{STD}_{i t}=$ change in long-term debt included in current liabilities; Dep $_{i t}=$ depreciation and amortization expenses. We use the cross-sectional version of the modified Jones (1991) model to estimate the nondiscretionary component of total accruals (TAC) (DeFond and Jiambalvo 1991; Yeo et al. 2002).

$\frac{\mathrm{TAC}_{i t}}{A_{i, t-1}}=\beta_{0}+\beta_{1} \frac{\Delta R E V_{i t}}{A_{i, t-1}}+\beta_{2} \frac{\mathrm{PPE}_{i t}}{A_{i, t-1}}+\varepsilon_{i t}$

For each year and industry we regress total accruals (TAC) on the change in revenues ( $\triangle \mathrm{REV})$ and the level of gross property, plant and equipment (PPE), scaled by lagged total assets $\left(A_{t-1}\right)$ in order to avoid problems of heteroskedasticity. Using the estimates for the regression parameters, $(\hat{\beta} 0, \hat{\beta} 1, \hat{\beta} 2)$, we estimate each sample firm's non-discretionary accruals (NDCA) by adjusting the change in sales for the change in accounts receivable $(\triangle \mathrm{AR})$ to allow for the possibility that firms could have manipulated sales by changing credit terms (Dechow et al. 1995). 
$\mathrm{NDCA}_{i t}=\hat{\beta}_{0}+\hat{\beta}_{1} \frac{\Delta \mathrm{REV}_{i t}-\Delta \mathrm{AR}_{i t}}{A_{i, t-1}}+\hat{\beta}_{2} \frac{\mathrm{PPE}_{i t}}{A_{i, t-1}}$

And we define discretionary accruals $\left(\mathrm{DCA}_{i t}\right)$ for firm $i$ in year $t$ as the remaining portion of Total accruals:

$\mathrm{DAC}_{i t}=\frac{\mathrm{TAC}_{i t}}{A_{i, t-1}}-\mathrm{NDCA}_{i t}$

Thus, we use the absolute value of discretionary accruals $\left[\mathrm{Abs}(\mathrm{DCA})_{i t}\right]$ as a measure of the degree of EM. This is consistent with previous studies on earnings management which point out that the study of the quality of results does not impose any direction or sign on the expectations of EM (Wartfield et al. 1995; Gabrielsen et al. 2002; Wang 2006; Chen et al. 2007; Barth et al. 2008).

\section{Models and Variables Definition}

Since the aim is to investigate the influence that CG mechanisms have on EM, measured by discretionary accruals, we regress the absolute value of discretionary accruals $\left[\mathrm{Abs}(\mathrm{DCA})_{i t}\right]$ on the variables of ownership structure, Board of Directors and control used in previous literature, according to the following model:

$$
\begin{aligned}
\operatorname{Abs}(\mathrm{DAC})_{i t}= & \beta_{0}+\beta_{1}\left(\mathrm{Int} \_\mathrm{OWN}\right)+\beta_{2}\left(\mathrm{OWN} \_\mathrm{Con}\right) \\
& +\beta_{3}(\text { Fam_OWN })+\beta_{4}(\text { Inst_OWN }) \\
& +\beta_{5}(\text { Board_SIZE })+\beta_{6}(\text { Board_IND }) \\
& +\beta_{7}(\text { Board_ACT })+\beta_{8}\left(\mathrm{CEO} \_D u a l\right) \\
& +\beta_{9}\left(\mathrm{GOV} \_ \text {Index }\right)+\beta_{10}(\text { Control })+\eta_{i} \\
& +\lambda_{t}+v_{i t}
\end{aligned}
$$

The unobserved heterogeneity is controlled in the two models through individual effects of companies $\left(\eta_{i}\right)$. Also, we included dummy variables to control the temporal effects $\left(\lambda_{i t}\right)$ and the error term $\left(v_{i t}\right)$. As a proxy for internal property (Int_OWN) we use the proportion of shares $\geq 1 \%$ owned by members of Board of Directors and managers of the firms; the ownership concentration (OWN_Con) is measured by the proportion of shares owned by the major shareholder of the company, because many firms in Latin America are directly controlled by one of the industrial or financial conglomerates that operate in the region (Lopez and Saona 2005; Cespedes et al. 2008); family ownership (Fam_OWN) is measured by the proportion of shares held by family members, i.e., the percentage of capital that is directly or indirectly in their hands $\geq 5 \%$ and; institutional ownership (Inst_OWN) through the proportion of shares held by institutional investors. Board size (Board_SIZE) is measured by the total number of directors that integrate the Board of Directors; Board independence (Board_IND) is measured by the proportion of external directors inside the Board (external directors/total directors) and with a dummy variable (Board_IND50) that takes the value of one when the Board comprises a majority of external directors; Board activity (Board_ACT) is measured by the number of meetings held during the year; President-CEO duality (CEO_Dual) is measured through a dummy variable that considers the value of 1 if there is duality of roles between the chairman and CEO of the firm and, 0 otherwise. Finally, there is the government Index (Gov_Index), which measures the governability level of the country (control of corruption, rule of law and government effectiveness).

We also control the effect of various factors through the inclusion of variables which have been used in previous studies and have been associated with EM and CG. Thus, we include the variable quality and reputation of the external auditor (Big_4) measured by a dummy variable that takes the value 1 if the company is audited by one of the big four audit firms, 0 otherwise. Several studies thus indicate that quality of accounting information will be linked to the prestige and quality of the external auditor (Lennox 1999; Jara and López 2007), because more reputable auditors limit the possibility of EM and therefore, the financial statements audited by these firms have greater credibility (DeFond and Subramanyam 1998; Teoh et al. 1998).

Another control variable is firm size (Log_ASSET) measured by the natural logarithm of total assets at the end of year (Sanchez and Sierra 2001), controlling with it the effects of company size on accounting choice. Authors generally expect, and often prove, a negative relation between firm size and EM, given that larger companies are expected to have more sophisticated control systems, skilled advisers, more negotiating power with the external auditor and are subject to increased monitoring by investors and analysts, so accounting fraud is less probable than in smaller firms, where the managers of these companies have more opportunities to manipulate the information (Goodwin and Kent 2006; Prior et al. 2008). We also include the indebtedness level variable (Debt), calculated as the ratio of total debt and total assets. Thus, a high indebtedness is associated with the risk of excessive leverage (Press and Weintrop 1990), which motivates the EM to conceal inconvenient information and display a greater capacity to generate resources (Dechow et al. 1995; Krishnan et al. 1996; Balsam et al. 2003).

Additionally, following Francis and Wang (2004) we include two control variables on firm performance. The first is the growth variable (GROWTH), measured in terms of the relation of the difference in sales and sales of the previous period for firm $i$ in year $t$, which indicates that companies with high growth rates are more likely to use discretionary accruals (McNichols 2000). The second is the variable (ROA), calculated by the ratio between earnings before extraordinaire, interest and taxes of year $t$ and the 
Table 1 Descriptive statistics of discretionary accruals [Abs(DCA $)_{i t}$ ] estimations by year

\begin{tabular}{lrlllrl}
\hline Years & $N$ & Mean & Median & SD & $T$ & $\begin{array}{l}\text { Adjusted } \\
R^{2}\end{array}$ \\
\hline DAC-2006 & 435 & 0.224 & 0.119 & 0.441 & 0.619 & 0.536 \\
DAC-2007 & 435 & 0.278 & 0.112 & 0.704 & -1.070 & 0.285 \\
DAC-2008 & 435 & 0.198 & 0.122 & 0.293 & 1.567 & 0.118 \\
DAC-2009 & 435 & 0.249 & 0.142 & 0.420 & -0.243 & 0.808 \\
Global & 1,740 & 0.237 & 0.121 & 0.489 & 1.459 & 0.447 \\
\hline
\end{tabular}

total net assets at beginning of year $t$, and positively related to the use of discretionary accruals. This suggests that managers are motivated to manipulate the results upward, i.e., increase the profits obtained with the intention of making the company more attractive (Kothari et al. 2005; Machuga and Teitel 2007).

Also, because a poor financial situation of the company could increase agency costs and encourage the management to manipulate the accounting numbers (Nurul et al. 2010) we include the control variable loss (Loss) which is measured through a dummy variable that takes value of 1 if the company has had losses in the last 2 years and, 0 otherwise. Finally, we consider the sector of activity variables (IND) and year (YEAR), which are important factors of measurement because sectors and specific years could have a better results by identifying discretionary accruals (Roychowdhury 2006).

\section{Analysis and Results}

\section{Descriptive Analysis}

Table 1 displays the descriptive statistics and $t$ values of discretionary accruals for estimated $\left[\mathrm{Abs}(\mathrm{DCA})_{i t}\right]$, showing that mean values of discretionary accruals are, in all cases, statistically different from zero. This does not allow us to reject the null hypothesis and, therefore, provides evidence that Latin American companies manipulate their results, either by increasing profits to denote a better and higher profitability of the company or, on the contrary, reducing them as fiscal strategy aims to pay fewer taxes and contributions.

Table 2 shows the mean, median, standard deviation and the associated $t$ value of the estimated coefficients of the absolute value of discretionary accruals $\left[\mathrm{Abs}(\mathrm{DCA})_{i t}\right]$ per country. It can be seen that the model significantly explains variations in the coefficients of discretionary accruals, as its explanatory power shows Adjusted $R^{2}$ values (significance level) above $40 \%$ for all the countries.
Table 2 Descriptive statistics of discretionary accruals [Abs(DCA $\left.)_{i t}\right]$ estimations by country

\begin{tabular}{lrlllll}
\hline Country & \multicolumn{1}{l}{$N$} & Mean & Median & SD & $T$ & Adjusted $R^{2}$ \\
\hline Argentina & 308 & 0.247 & 0.137 & 0.425 & 0.412 & 0.744 \\
Brazil & 480 & 0.293 & 0.152 & 0.481 & 1.749 & 0.476 \\
Chile & 532 & 0.236 & 0.101 & 0.651 & 1.852 & 0.542 \\
Mexico & 420 & 0.167 & 0.110 & 0.198 & 1.493 & 0.408 \\
Global & 1,740 & 0.237 & 0.121 & 0.489 & 1.459 & 0.447 \\
\hline
\end{tabular}

Table 3 shows the main descriptive statistics of quantitative and dichotomous variables. Thus, with respect the Board characteristics variables it can be seen that in the four countries analyzed, generally, companies Boards meets on average 5 times a year. It can also be seen that Boards are composed of a mean of 11 members, of whom $38.5 \%$ are external directors, a fact that clearly indicates that the composition of this organ of government is a majority of internal members, thus demonstrating control and dominion among those that have families on this governing body.

Regarding ownership structure, Table 3 shows that Mexican companies have highest family engagement, with $37.1 \%$, followed by Argentinian (35\%), Chilean (26.2 \%), and Brazilian (24\%) companies. The ownership concentration (major shareholder) reflects an average of $29.4 \%$ of the social capital of firms. Hence, Chilean companies are those that revealed have a higher shareholding concentration with $32.2 \%$, followed by Brazilian (29.3\%), Mexican $(28.6 \%)$, and Argentinean (27.5\%) firms. Moreover, regarding the internal ownership (top management), it can be seen that manager and directors holds, on average, $6.1 \%$ of the social capital of companies. Thus, Brazilian firms are those that revealed have a higher internal ownership with $7.3 \%$, followed by Argentinean (7.1\%), Chilean (6\%), and Mexican (4.5\%) companies. Finally, the institutional ownership indicates an average value of $22.8 \%$ of social capital held by institutional investors. Thus, Brazilian companies are those that have revealed a higher participation of institutional investors with $23.9 \%$, followed by the Chilean $(23.8 \%)$, Argentinean (21\%), and Mexican (20.6\%) firms.

\section{Regression Results}

After analyzing the variables descriptively, it is necessary to apply tests to help measure the linear relation between the dependent variable "absolute value of discretionary accruals $\left[\mathrm{Abs}(\mathrm{DCA})_{i t}\right]$ " and the independent and control variables of the firms. The explanatory development is based mainly on determining the level of influence that $\mathrm{CG}$ mechanisms has on discretionary accruals. In order to determine which model is best suited to our data, (the fixed 
Table 3 Descriptive statistics of quantitative and dichotomous variables observations by country

\begin{tabular}{|c|c|c|c|c|c|c|}
\hline Variable & $\begin{array}{l}\text { Statistics } \\
N\end{array}$ & $\begin{array}{l}\text { Argentina } \\
308\end{array}$ & $\begin{array}{l}\text { Brazil } \\
480\end{array}$ & $\begin{array}{l}\text { Chile } \\
532\end{array}$ & $\begin{array}{l}\text { Mexico } \\
420\end{array}$ & $\begin{array}{l}\text { Global } \\
1,740\end{array}$ \\
\hline \multicolumn{7}{|c|}{ Quantitative variables } \\
\hline \multirow[t]{2}{*}{ Int_OWN } & Mean & 0.071 & 0.073 & 0.060 & 0.045 & 0.061 \\
\hline & Std. Dev. & 0.046 & 0.048 & 0.047 & 0.038 & 0.046 \\
\hline \multirow[t]{2}{*}{ OWN_Con } & Mean & 0.275 & 0.293 & 0.322 & 0.286 & 0.294 \\
\hline & Std. Dev. & 0.106 & 0.102 & 0.118 & 0.101 & 0.107 \\
\hline \multirow[t]{2}{*}{ Fam_OWN } & Mean & 0.350 & 0.240 & 0.262 & 0.371 & 0.305 \\
\hline & Std. Dev. & 0.163 & 0.177 & 0.181 & 0.181 & 0.179 \\
\hline \multirow[t]{2}{*}{ Inst_OWN } & Mean & 0.210 & 0.239 & 0.238 & 0.206 & 0.228 \\
\hline & Std. Dev. & 0.145 & 0.136 & 0.135 & 0.135 & 0.137 \\
\hline \multirow[t]{2}{*}{ Board_SIZE } & Mean & 11.49 & 11.38 & 11.54 & 11.47 & 11.47 \\
\hline & Std. Dev. & 3.82 & 3.69 & 3.60 & 3.66 & 3.67 \\
\hline \multirow[t]{2}{*}{ Board_IND } & Mean & 0.400 & 0.394 & 0.366 & 0.375 & 0.385 \\
\hline & Std. Dev. & 0.730 & 0.891 & 0.077 & 0.862 & 0.083 \\
\hline \multirow[t]{2}{*}{ Board_ACT } & Mean & 5.42 & 5.37 & 5.33 & 5.15 & 5.31 \\
\hline & Std. Dev. & 2.49 & 2.50 & 2.47 & 2.38 & 2.46 \\
\hline \multirow[t]{2}{*}{ GOV_Index } & Mean & 41.13 & 51.12 & 88.05 & 48.78 & 49.73 \\
\hline & Std. Dev. & 3.25 & 2.51 & 0.68 & 2.06 & 18.78 \\
\hline \multirow[t]{2}{*}{ Log_ASSET } & Mean & 13.32 & 13.39 & 18.39 & 16.09 & 15.58 \\
\hline & Std. Dev. & 1.91 & 1.75 & 2.32 & 1.70 & 2.93 \\
\hline \multirow[t]{2}{*}{ Debt } & Mean & 0.396 & 0.504 & 0.280 & 0.227 & 0.350 \\
\hline & Std. Dev. & 1.371 & 0.691 & 0.924 & 0.158 & 0.862 \\
\hline \multirow[t]{2}{*}{ ROA } & Mean & 4.47 & 4.58 & 9.18 & 6.96 & 6.56 \\
\hline & Std. Dev. & 1.84 & 1.67 & 2.36 & 1.70 & 2.79 \\
\hline \multirow[t]{2}{*}{ GROWTH } & Mean & 0.236 & 0.531 & 0.103 & 0.124 & 0.249 \\
\hline & Std. Dev. & 0.617 & 2.221 & 0.299 & 0.484 & 1.241 \\
\hline \multicolumn{7}{|c|}{ Dichotomous variables } \\
\hline \multirow[t]{2}{*}{ Board_IND50 } & 0 & $148(48.1 \%)$ & $240(50.0 \%)$ & $316(59.4 \%)$ & $224(53.3 \%)$ & $928(53.3 \%)$ \\
\hline & 1 & $160(51.9 \%)$ & $240(50.0 \%)$ & $216(40.6 \%)$ & $196(46.7 \%)$ & $812(46.7 \%)$ \\
\hline \multirow[t]{2}{*}{ CEO_Dual } & 0 & $99(32.1 \%)$ & $193(40.2 \%)$ & $209(39.3 \%)$ & $172(40.9 \%)$ & $673(38.7 \%)$ \\
\hline & 1 & $209(67.9 \%)$ & $287(59.8 \%)$ & $323(60.7 \%)$ & $248(59.1 \%)$ & $1,067(61.3 \%)$ \\
\hline \multirow[t]{2}{*}{ Big_4 } & 0 & $144(46.8 \%)$ & $199(41.5 \%)$ & $180(33.8 \%)$ & $120(28.6 \%)$ & $643(36.9 \%)$ \\
\hline & 1 & $164(53.2 \%)$ & $281(58.5 \%)$ & $352(66.2 \%)$ & $300(71.4 \%)$ & $1,097(63.1 \%)$ \\
\hline \multirow[t]{2}{*}{ Loss } & 0 & $234(76.0 \%)$ & $373(77.7 \%)$ & $436(81.9 \%)$ & $319(75.9 \%)$ & $1,362(78.3 \%)$ \\
\hline & 1 & $74(24.0 \%)$ & $107(22.3 \%)$ & $96(18.1 \%)$ & $101(24.1 \%)$ & $378(21.7 \%)$ \\
\hline
\end{tabular}

Quantitative variables: Int_OWN Internal ownership, measured by the proportion of shares owned by managers and members of Boards ( $\geq 1 \%$ ); $O W N \_C o n$ Ownership Concentration, measured by the ratio of shares held by the major shareholder of the company ( $\left.\geq 5 \%\right)$; Fam_OWN Family Ownership, measured by the proportion of shares held by family members $(\geq 5 \%)$, as a percentage of capital that is directly or indirectly in his possession; Inst_OWN Institutional Ownership, measured by the proportion of shares held by institutional investors; Board_SIZE Size of boards of directors, measured by the total number of members of Boards; Board_IND independence of the Board, measured by the proportion of independent members (independent directors/total directors); Board_ACT Activity of Boards, measured by the number of meetings; GOV_Index The degree of law enforcement of each country analyzed, taken from the research project "Worldwide Governance Indicators" (WGI) proposed by Kaufmann et al. (2010); Log_ASSET Firm size, measured by the natural logarithm of total assets of the companies; Debt Level of indebtedness, measured by the quotient resulting from gross debt to total assets; ROA Economic Return, measured by the ratio of the relationship between the result before special items, interest and taxes of year $t$ and the total net assets at the beginning of year $t$; GROWTH Growth of the Companies, calculated in terms of the ratio of the difference in sales and sales of the previous period of firm $i$ in year $t$

Dichotomous variables: Boad_IND50 Measured through a dummy variable that takes value of 1 if boards has a majority of independent directors and, 0 otherwise; $C E O \_$Dual Measured through a dummy variable that considers the value of 1 if there is duality of roles between the chairman and CEO of the companies and, 0 otherwise; Big_4 Measured by a dummy variable that takes the value 1 if the firms are audited by one of the big four firms, 0 otherwise; Loss Measured through a dummy variable that takes value of 1 if the companies have had losses in the last 2 years and, 0 otherwise 
effects based on groups estimator or random effects based on generalized least squares (GLS)), we perform the Hausman test (1978), which determines whether the differences are systematic and significant between the two models. In all cases, the result of this test does not reject the null hypothesis of no systematic differences between the regressors' and unobserved heterogeneity, therefore assuming the random effects as the most appropriate for our analysis.

Thus, in Table 4 the model 10 shows the results obtained from the linear regression of the panel data, the absolute value of discretionary accruals $\left[\mathrm{Abs}(\mathrm{DCA})_{i t}\right]$ on the variables of ownership structure, Board of Directors and control. With regard to the internal ownership, is observed that the stake held by managers and directors in Latin American firms have a significant negative relation at level of $1 \%$ with the absolute value of discretionary accruals. The findings show a significant negative relation at level of $1 \%$ with ownership concentration and board size (5\%).

In addition, the model 10 shows that Board activity has a negative relation, significant at level of $5 \%$, showing that the greater number of meetings held by the Boards decreases the use of discretionary accruals. We do not find any statistically significant relation between family ownership (Fam_OWN), institutional ownership (Inst_OWN), CEO duality (CEO_Dual), and the absolute value of discretional accruals.

On the other hand, there is a significant negative relation at the $1 \%$ level between Government Index (GOV_Index) and discretionary accruals. Finally, in the remaining control variables it can be seen that they maintain their level of significance and the expected sign: there is a significant negative relation at the $5 \%$ level between firm size and discretionary accruals and a significant positive relation at the $1 \%$ level between discretionary accruals and level of debt, economic profitability and growth.

Additionally, in model 11 of Table 4 we use a different proxy for Board independence, replacing the proportion of external directors on Boards (Board_IND) by a dummy variable that takes the value of 1 if Board has a majority of external directors, and 0 otherwise (Board_IND50). The conclusions are the same as model 10, i.e., the Board independence also shows a weak negative relation significant at the $10 \%$ level with the dependent variable $\left[\mathrm{Abs}(\mathrm{DCA})_{i t}\right]$.

\section{Analysis Extension}

\section{Non-linear Relations}

In this section we extend the previous analyzes to test the possible nonlinear relations between CG mechanisms and EM. As we have shown in the literature review section, there are competing views about the effect of certain governance characteristics on earnings management. Thus, we have re-tested model 10 , including the quadratic terms for insider ownership, ownership concentration and board activity. With these analyses we will try to explain if a U-shape relation could explain the ambiguous outcome regarding these variables.

Thus, since previous studies have found non-linearities which support both the convergence-of-interests and the entrenchment hypotheses in different ownership intervals (Morck et al. 1988; Yeo et al. 2002), we examine the possible non-linearities in the relation between insider ownership and discretionary accruals. In Table 5, model (12), we test the non linear effect of insider ownership (Int_OWN and Int_OWN2) on earnings management along with the other governance and control variables. Similarly in models (13) and (14) we check the non-linearities of ownership concentration (OWN_Con and OWN_Con2) and board activity (Board_ACT and Board_ACT2).

In model (15) we report the results when we take into account the non-linearities in the three variables (Int_OWN, OWN_Con, Board_ACT). This model shows that the linear and quadratic terms of the internal ownership are significant at the 1 and $5 \%$ levels, respectively, with the linear term negative and the quadratic term positive, suggesting that when the ownership of the insiders increases it reduces the EM by managers (Weisbach 1988; Fernandez 1998; Cornett et al. 2008), but, as we can observe in Table 6, when the internal ownership reaches a certain point, ${ }^{4}$ which is around $14.1 \%$, the situation is reversed with an increase in manipulative practices by insiders.

Additionally, Table 5 shows that for the concentration of shares held by major shareholders, the linear and quadratic term are significant at the 1 and $5 \%$ levels, respectively, with the linear term negative and the quadratic positive, indicating that ownership concentration is also a mechanism that could restrict the manipulative practices when the proportion of shares held by major shareholders is not very high (efficient monitoring hypothesis). Table 7 shows the non-linear relation in detail, indicating that when ownership concentration reaches a certain point, ${ }^{5}$ which is located around $35.1 \%$, there is an increase in the use of discretionary accruals.

\footnotetext{
${ }^{4}$ This minimum is calculated by differentiating the dependent variable with respect to the internal ownership and equating to zero, and $\partial / \partial x=0$, thus obtaining the value of internal ownership that verifies this condition and proving that $2 y \partial / \partial x>0$, which implies that this point is a minimum.

5 This minimum is calculated by differentiating the dependent variable with respect to the ownership concentration and equating to zero, and $\partial / \partial x=0$, thus obtaining the value of the ownership concentration that verifies this condition and proving that $2 y \partial / \partial x>0$, which implies that this point is a minimum.
} 


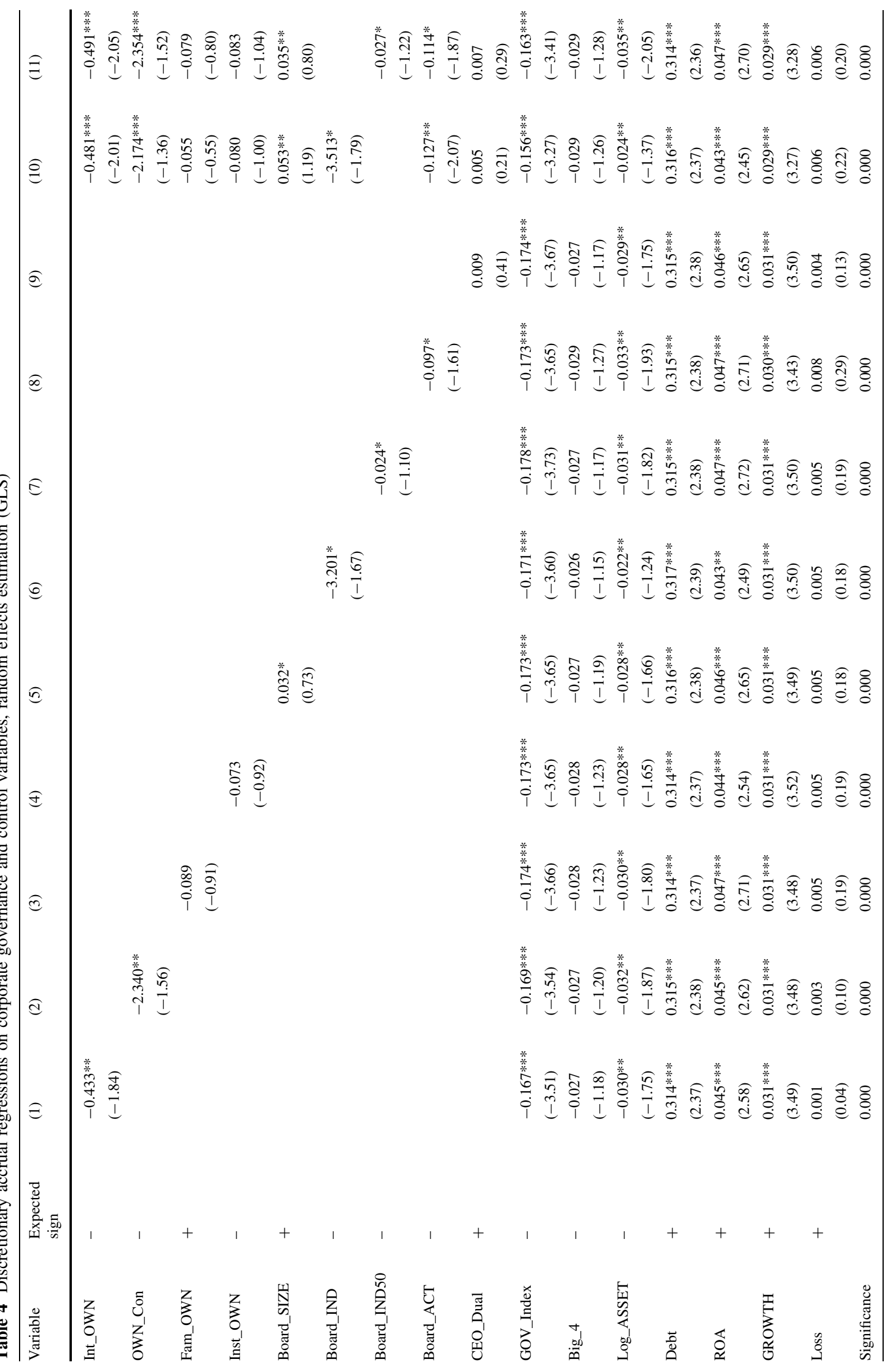




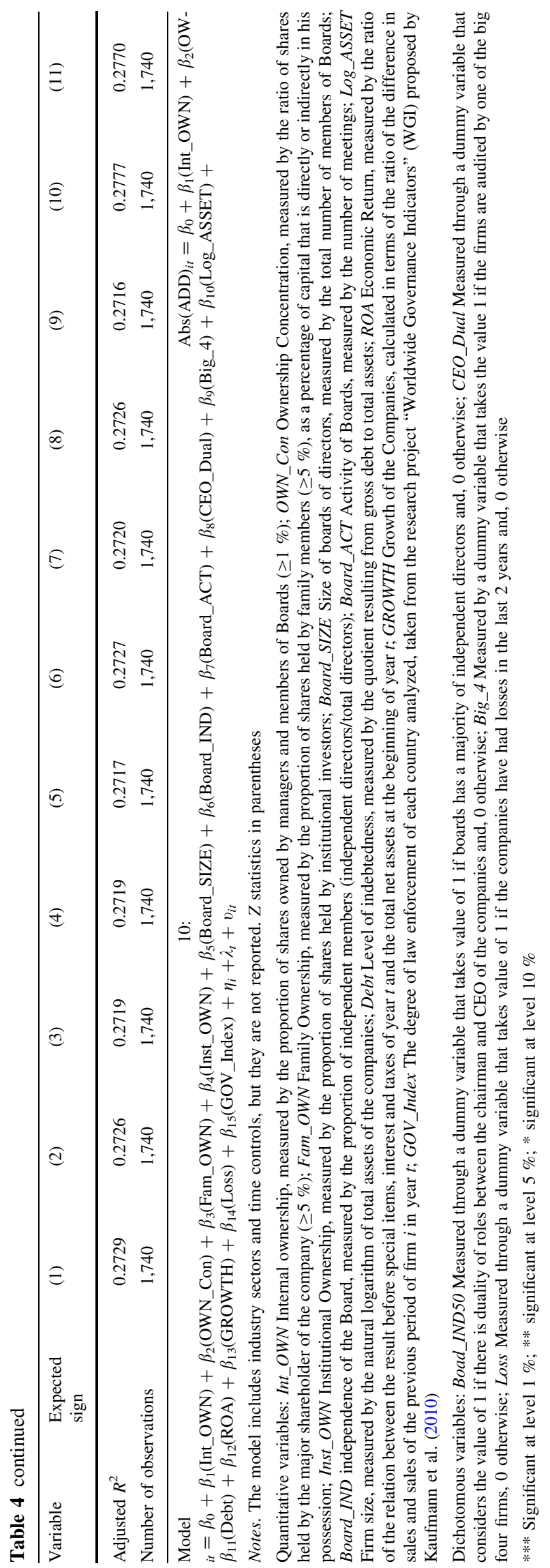

Finally, concerning the Boards activity, in Table 5 the full model shows that the linear term has a weak negative significance at level of $10 \%$ and the quadratic term is positive but not significant, providing an explanation for the contradictory effect of Board activity.

\section{Robustness Analysis}

In order to verify the robustness between models, Table 8 shows the comparison of the results exposed in previous section with other models also used in literature to measure the quality of results, like the original version of the Jones model (1991), the Jones cash flow model used by Jeter and Shivakumar (1999) and, the KS model proposed by Kang and Sivaramakrishnan (1995). Thus, it is observed that the original Jones model, the Jones cash flow model and the KS model shows qualitatively similar results to those obtained through the Modified Jones model, so demonstrating the robustness of the tests.

\section{Discussion}

Our study has analyzed the effects of CG over the earnings management, measured by discretionary accruals, for a set of non-financial companies listed on Latin American stock markets, specifically, listed companies in markets of Argentina, Brazil, Chile, and Mexico.

In relation to the participation of the management team on firms' ownership, our results show a non-linear relation between insiders ownership and discretionary accruals that suggests that internal ownership is a mechanism that, despite differences in CG systems, may restrict the use of discretionary accruals only when the proportion of shares owned by the insiders is not very high. Our result is in line with those obtained by Machuga and Teitel (2009) with a sample of Mexican firms, who show that firms with less internal ownership show a greater earnings quality compared to those that do not have managerial ownership, i.e., shows less manipulative practices by managers, because of the implementation of good CG practices contained in Codes of Best Practices. Likewise, other studies such as Morck et al. (1988) in Canada, Wartfield et al. (1995) in the US, Yeo et al. (2002) in Singapore and Sanchez-Ballesta and Garcia-Meca (2007) in Spain, also point out that the informativeness of accounting results increases with low levels of internal ownership, while for a high levels, the internal ownership is not sufficient as a mechanism of interest alignment.

Regarding the influence of ownership concentration, the results confirm hypothesis $\mathrm{H} 2$ and suggest that when the main shareholders have a high percentage of ownership or when a conglomerate directly controls the firm, the 
Table 5 Non-linear relation in internal ownership, ownership concentration and board activity

\begin{tabular}{|c|c|c|c|c|}
\hline Variables & (12) & (13) & (14) & (15) \\
\hline Int_OWN & $\begin{array}{l}-0.978^{* * *} \\
(-1.06)\end{array}$ & $\begin{array}{l}-0.456 * * \\
(-1.90)\end{array}$ & $\begin{array}{l}-0.486^{* *} \\
(-2.03)\end{array}$ & $\begin{array}{l}-0.873^{* * * *} \\
(0.94)\end{array}$ \\
\hline Int_OWN2 & $\begin{array}{l}2.888^{* *} \\
(0.55)\end{array}$ & & & $\begin{array}{l}2.401 * * \\
(0.46)\end{array}$ \\
\hline OWN_Con & $\begin{array}{l}-2.150^{* *} \\
(-1.35)\end{array}$ & $\begin{array}{l}-2.101^{* * *} \\
(-1.17)\end{array}$ & $\begin{array}{l}-2.099 * * \\
(-1.32)\end{array}$ & $\begin{array}{l}-2.126 * * * \\
(-1.47)\end{array}$ \\
\hline OWN_Con2 & & $\begin{array}{l}1.749 * * \\
(1.46)\end{array}$ & & $\begin{array}{l}1.540^{* *} \\
(1.54)\end{array}$ \\
\hline Fam_OWN & $\begin{array}{l}-0.057 \\
(-0.58)\end{array}$ & $\begin{array}{l}-0.063 \\
(-0.64)\end{array}$ & $\begin{array}{l}-0.056 \\
(-0.56)\end{array}$ & $\begin{array}{l}-0.068 \\
(-0.68)\end{array}$ \\
\hline Inst_OWN & $\begin{array}{l}-0.079 \\
(-0.99)\end{array}$ & $\begin{array}{l}-0.076 \\
(-0.95)\end{array}$ & $\begin{array}{l}-0.078 \\
(-0.98)\end{array}$ & $\begin{array}{l}-0.074 \\
(-0.92)\end{array}$ \\
\hline Board_SIZE & $\begin{array}{l}0.053^{*} \\
(1.20)\end{array}$ & $\begin{array}{l}0.051^{*} \\
(1.15)\end{array}$ & $\begin{array}{l}0.047^{*} \\
(1.06)\end{array}$ & $\begin{array}{l}0.044^{*} \\
(0.99)\end{array}$ \\
\hline Board_IND & $\begin{array}{l}-3.556^{*} \\
(-1.81)\end{array}$ & $\begin{array}{l}-3.190 * \\
(-1.62)\end{array}$ & $\begin{array}{l}-3.534^{*} \\
(-1.80)\end{array}$ & $\begin{array}{l}-3.231^{*} \\
(-1.64)\end{array}$ \\
\hline Board_ACT & $\begin{array}{l}-0.124 * \\
(-2.03)\end{array}$ & $\begin{array}{l}-0.134 * \\
(-2.18)\end{array}$ & $\begin{array}{l}-0.191 * \\
(-0.94)\end{array}$ & $\begin{array}{l}-0.134 * \\
(-0.55)\end{array}$ \\
\hline Board_ACT2 & & & $\begin{array}{l}0.094 \\
(0.39)\end{array}$ & $\begin{array}{l}0.231 \\
(1.13)\end{array}$ \\
\hline CEO_Dual & $\begin{array}{l}0.004 \\
(0.20)\end{array}$ & $\begin{array}{l}0.005 \\
(0.23)\end{array}$ & $\begin{array}{l}0.006 \\
(0.27)\end{array}$ & $\begin{array}{l}0.007 \\
(0.31)\end{array}$ \\
\hline GOV_Index & $\begin{array}{l}-0.156^{* * *} \\
(-3.28)\end{array}$ & $\begin{array}{l}-0.160 * * * \\
(-3.35)\end{array}$ & $\begin{array}{l}-0.154 * * * \\
(-3.23)\end{array}$ & $\begin{array}{l}-0.159^{* * *} \\
(-3.32)\end{array}$ \\
\hline Big_4 & $\begin{array}{l}-0.027 \\
(-1.20)\end{array}$ & $\begin{array}{l}-0.027 \\
(-1.21)\end{array}$ & $\begin{array}{l}-0.029 \\
(-1.27)\end{array}$ & $\begin{array}{l}-0.027 \\
(-1.17)\end{array}$ \\
\hline Log_ASSET & $\begin{array}{l}-0.025^{* *} \\
(-1.38)\end{array}$ & $\begin{array}{l}-0.026^{* *} \\
(-1.47)\end{array}$ & $\begin{array}{l}-0.024 * * \\
(-1.37)\end{array}$ & $\begin{array}{l}-0.028^{* *} \\
(-1.49)\end{array}$ \\
\hline Debt & $\begin{array}{l}0.317 * * * \\
(2.37)\end{array}$ & $\begin{array}{l}0.316 * * * \\
(2.37)\end{array}$ & $\begin{array}{l}0.316 * * * \\
(-2.36)\end{array}$ & $\begin{array}{l}0.315 * * * \\
(2.34)\end{array}$ \\
\hline ROA & $\begin{array}{l}0.043 * * \\
(2.47)\end{array}$ & $\begin{array}{l}0.044 * * * \\
(2.52)\end{array}$ & $\begin{array}{l}0.044 * * \\
(2.49)\end{array}$ & $\begin{array}{l}0.046 * * * \\
(2.60)\end{array}$ \\
\hline GROWTH & $\begin{array}{l}0.029 * * * \\
(3.26)\end{array}$ & $\begin{array}{l}0.029 * * * \\
(3.25)\end{array}$ & $\begin{array}{l}0.028 * * * \\
(3.23)\end{array}$ & $\begin{array}{l}0.028 * * * \\
(3.21)\end{array}$ \\
\hline Loss & $\begin{array}{l}0.006 \\
(0.21)\end{array}$ & $\begin{array}{l}0.008 \\
(0.28)\end{array}$ & $\begin{array}{l}0.008 \\
(0.27)\end{array}$ & $\begin{array}{l}0.009 \\
(0.33)\end{array}$ \\
\hline Significance & 0.000 & 0.000 & 0.000 & 0.000 \\
\hline Adjusted $R^{2}$ & 0.2772 & 0.2786 & 0.2781 & 0.2792 \\
\hline $\begin{array}{l}\text { Number of } \\
\text { Observations }\end{array}$ & 1,740 & 1,740 & 1,740 & 1,740 \\
\hline
\end{tabular}

Model 15: $\operatorname{Abs}(\mathrm{ADD}){ }_{i t}=\beta_{0}+\beta_{1}($ Int_OWN $)+\beta_{2}($ Int_OWN2 $)+\beta_{3}($ OWN_Con $)+\beta_{4}\left(\mathrm{OWN} \_\right.$Con2 $)+\beta_{5}($ Fam_OWN $)+\beta_{6}($ Inst_OWN $)+\beta_{7}($ Board_SIZE $)+\beta_{8}($ Board IND $)+\beta_{9}$ (Board_ACT $)+\beta_{10}($ Board_ACT2 $)+\beta_{11}($ CEO_Dual $)+\beta_{12}($ Big 4$)+\beta_{13}\left(\log \_\right.$ASSET $)+\beta_{14}($ Debt $)+\beta_{15}($ ROA $)+\beta_{16}($ GROWTH $)+-$

$+\beta B o \alpha \sigma \delta A \Gamma Y+\beta_{\varsigma} B o \alpha \sigma \delta A \Gamma Y+\beta_{\varsigma \varsigma} \Gamma E O \Delta \varphi \alpha \mu+\beta_{\varsigma} B \eta \eta+\beta_{\varsigma} M o \eta A T T E Y+\beta_{\xi} \Delta \varepsilon \beta v+\beta_{\varsigma} \Sigma O A+\beta_{\varsigma} H \Sigma O \Psi Y \Theta+\beta_{\varsigma} M o \tau \tau+\beta_{\varsigma} H O X$

$I \xi \delta \varepsilon \omega+\eta_{i}+\lambda_{t}+v_{i t}$

*** Significant at level $1 \%, * *$ significant at level $5 \%$, significant at level $10 \%$

Notes. The model includes industry sectors and time controls, but they are not reported. $Z$ statistics in parentheses

Quantitative variables: Int_OWN Internal ownership, measured by the proportion of shares owned by managers and members of Boards ( $\geq 1 \%)$; OWN_Con Ownership Concentration, measured by the ratio of shares held by the major shareholder of the company ( $\geq 5 \%$ ); Fam_OWN Family Ownership, measured by the proportion of shares held by family members $(\geq 5 \%)$, as a percentage of capital that is directly or indirectly in his possession; Inst_OWN Institutional Ownership, measured by the proportion of shares held by institutional investors; Board_SIZE Size of boards of directors, measured by the total number of members of Boards; Board_IND independence of the Board, measured by the proportion of independent members (independent directors/total directors); Board_ACT Activity of Boards, measured by the number of meetings; Log_ASSET Firm size, measured by the natural logarithm of total assets of the companies; Debt Level of indebtedness, measured by the quotient resulting from gross debt to total assets, ROA Economic Return, measured by the ratio of the relation between the result before special items, interest and taxes of year $t$ and the total net assets at the beginning of year $t$; GROWTH Growth of the Companies, calculated in terms of the ratio of the difference in sales and sales of the previous period of firm $i$ in year $t ; G O V \_$Index The degree of law enforcement of each country analyzed, taken from the research project "Worldwide Governance Indicators" (WGI) proposed by Kaufmann et al. (2010)

Dichotomous variables: Boad_IND50 Measured through a dummy variable that takes value of 1 if boards has a majority of independent directors and, 0 otherwise; CEO_Dual Measured through a dummy variable that considers the value of 1 if there is duality of roles between the chairman and CEO of the companies and, 0 otherwise; Big 4 Measured by a dummy variable that takes the value 1 if the firms are audited by one of the big four firms, 0 otherwise; Loss Measured through a dummy variable that takes value of 1 if the companies have had losses in the last 2 years and, 0 otherwise 
Table 6 Discretionary accruals by ranks of internal ownership

\begin{tabular}{llll}
\hline Rank (\%) & {$\left[\operatorname{Abs}(\mathrm{DCA})_{i t}\right]^{\mathrm{a}}$} & Rank $(\%)$ & {$\left[\operatorname{Abs}(\mathrm{DCA})_{i t}\right]^{\mathrm{a}}$} \\
\hline $0.0-1.0$ & 0.7283 & $10.1-11.0$ & 0.1744 \\
$1.1-2.0$ & 0.5128 & $11.1-12.0$ & 0.1696 \\
$2.1-3.0$ & 0.3766 & $12.1-13.0$ & 0.1669 \\
$3.1-4.0$ & 0.3302 & $13.1-14.0$ & 0.1471 \\
$4.1-5.0$ & 0.3183 & $14,1-15.0$ & 0.1879 \\
$5.1-6.0$ & 0.2580 & $15.1-16.0$ & 0.2008 \\
$6.1-7.0$ & 0.2251 & $16.1-17.0$ & 0.2108 \\
$7.1-8.0$ & 0.2184 & $17.1-18.0$ & 0.2370 \\
$8.1-9.0$ & 0.2126 & $18.1-19.0$ & 0.2374 \\
$9.1-10.0$ & 0.1975 & $19.1-20.0$ & 0.2390 \\
\hline
\end{tabular}

a Absolute value of discretionary accruals estimated from the Jones Modified Model

Table 7 Discretionary accruals by ranks of ownership concentration

\begin{tabular}{llll}
\hline Rank $(\%)$ & {$\left[\operatorname{Abs}(\mathrm{DCA})_{i t}\right]^{\mathrm{a}}$} & Rank $(\%)$ & {$\left[\operatorname{Abs}(\mathrm{DCA})_{i t}\right]^{\mathrm{a}}$} \\
\hline $10.0-15.0$ & 0.2208 & $35.1-40.0$ & 0.2213 \\
$15.1-20.0$ & 0.2200 & $40.1-45.0$ & 0.2378 \\
$20.1-25.0$ & 0.2143 & $45.1-50.0$ & 0.2572 \\
$25.1-30.0$ & 0.2067 & $50.1-55.0$ & 0.2827 \\
$30.1-35.0$ & 0.1967 & $55.1-60.0$ & 0.3303 \\
\hline
\end{tabular}

a Absolute value of discretionary accruals estimated from the Jones Modified Model

absolute value of discretionary accruals is reduced, due to the efficient monitoring hypothesis indicated by Agency theory (Jensen and Meckling 1976; Fama 1980; Fama and Jensen 1983). The findings are also consistent with Fernandez et al. (1998), Yeo et al. (2002), Gabrielsen et al. (2002), and De Bos and Donker (2004), who note the monitoring role of external block holders, and their strong positive effects on earnings informativeness. However, the findings note that ownership concentration is also a mechanism that could restrict the manipulative practices when the proportion of shares held by major shareholders is not very high (efficient monitoring hypothesis). Above $35.1 \%$ concentration, an increase in the use of discretionary accruals is observed, confirming that environments with high ownership concentration promote the EM.

Therefore, our results confirm that insider ownership and ownership concentration are mechanisms that, in spite of the differences in corporate governance, may constrain discretionary accruals when the proportion of shares held by insiders or block holders is not too high. Nevertheless, when insiders and large shareholders own a large percentage of outstanding shares, they tend to make discretionary accounting choices.
Our results confirm hypothesis 5 and reveal how the dimension of Boards creates problems of communication and coordination that decreases the monitoring of the management team, thus increasing the EM. Also, our findings show that board independence has a weak negative relation, significant only at the $10 \%$, so we reject hypothesis 6 . Our result contrasts with the prominent role that both the theoretical and empirical literature has assigned to this attribute of the Board to safeguard the quality and transparency of results but, for the case of Latin American countries analyzed, it does not seem to be so effective.

In this regard, Price et al. (2006, 2007), Teitel and Machuga (2008), Chong et al. (2009), and Davila and Watkins (2009) in Mexico; Silveira et al. (2003), Schiehll and Santos (2004), and Ferraz et al. (2011) in Brazil; Iglesias (1999) in Chile; suggest that this is due to Boards' being mainly composed of major shareholders and managers of the companies, with external directors having a very limited participation, which facilitates the $\mathrm{EM}$ and the managerial discretion. It is probable that this evidence is derived, as stated by Yermack (2004), from the presence of grey directors, lack of rotation of the directors or both.

Grey directors are those that maintain some kind of family or professional relationship (present or past) with the company or its top management. The fact that in the annual reports of CG they are designated as external and almost in no way disclose any possible conflicts of interest could severely limit the Board independence. As regards the second, its slow or almost non-existent rotation makes them permanently external, and thus the report of the First Latin American Corporate Governance Survey, conducted by Price Waterhouse Cooper (PWC) in 2010 (published in 2011) indicates that on average only $12.35 \%$ of companies listed on Latin American stock markets put time limits for external directors. In short, according to Monterrey and Sanchez (2008), both groups might fall into the category that Eguidazu (1999) calls "the label", in which independence is an appearance and not an attitude, because the absence of sufficient distance from the management of the company could, in fact, concentrate power inside the Board, thereby facilitating EM (García Osma and Gill de Albornoz 2007).

Furthermore, concerning Board activity, a higher number of meetings can mean a greater involvement of Boards in tasks and monitoring activities and their taking a much more active position to safeguard the quality of financial information and, hence, reduce the use of discretionary accruals, which confirms $\mathrm{H} 7$.

Finally, we notice a significant negative relation at the $1 \%$ level between Government Index (GOV_Index) and discretionary accruals (hypothesis 9), suggesting that when a country implements controls aimed at reducing corruption, strengthening the rule of law or improving the 
Table 8 Comparison of models of discretionary accruals robustness test

\begin{tabular}{|c|c|c|c|c|}
\hline Variables & Jones Modified & Jones Original & Jones Cash Flow & KS \\
\hline Int_OWN & $\begin{array}{l}-0.481 * * * \\
(-2.01)\end{array}$ & $\begin{array}{l}-0.451^{* *} \\
(-2.25)\end{array}$ & $\begin{array}{l}-0.486^{* *} \\
(-2.14)\end{array}$ & $\begin{array}{l}-0.472 * * \\
(-2.33)\end{array}$ \\
\hline OWN_Con & $\begin{array}{l}-2.174 * * * \\
(-1.36)\end{array}$ & $\begin{array}{l}-2.374 * \\
(-1.82)\end{array}$ & $\begin{array}{l}-1.353^{*} \\
(-0.89)\end{array}$ & $\begin{array}{l}-1.883^{*} \\
(-1.39)\end{array}$ \\
\hline Fam_OWN & $\begin{array}{l}-0.055 \\
(-0.55)\end{array}$ & $\begin{array}{l}-0.035 \\
(-0.54)\end{array}$ & $\begin{array}{l}-0.069 \\
(-0.73)\end{array}$ & $\begin{array}{l}-0.036 \\
(-0.43)\end{array}$ \\
\hline Inst_OWN & $\begin{array}{l}-0.080 \\
(-1.00)\end{array}$ & $\begin{array}{l}-0.043 \\
(-0.62)\end{array}$ & $\begin{array}{l}-0.052 \\
(-0.69)\end{array}$ & $\begin{array}{l}-0.029 \\
(-0.43)\end{array}$ \\
\hline Board_SIZE & $\begin{array}{l}0.053^{* *} \\
(1.19)\end{array}$ & $\begin{array}{l}0.073^{*} \\
(1.91)\end{array}$ & $\begin{array}{l}0.041^{*} \\
(0.99)\end{array}$ & $\begin{array}{l}0.055^{*} \\
(1.47)\end{array}$ \\
\hline Board_IND & $\begin{array}{l}-3.513 * \\
(-1.79)\end{array}$ & $\begin{array}{l}-2.628 * \\
(-1.47)\end{array}$ & $\begin{array}{l}-2.419^{*} \\
(-1.30)\end{array}$ & $\begin{array}{l}-2.420 * \\
(-1.46)\end{array}$ \\
\hline Board_ACT & $\begin{array}{l}-0.127 * * \\
(-2.07)\end{array}$ & $\begin{array}{l}-0.025 * * \\
(-0.38)\end{array}$ & $\begin{array}{l}-0.141 * * \\
(-2.42)\end{array}$ & $\begin{array}{l}-0.027 * \\
(-0.53)\end{array}$ \\
\hline CEO_Dual & $\begin{array}{l}0.005 \\
(0.21)\end{array}$ & $\begin{array}{l}0.005 \\
(0.34)\end{array}$ & $\begin{array}{l}0.005 \\
(0.25)\end{array}$ & $\begin{array}{l}0.007 \\
(0.38)\end{array}$ \\
\hline GOV_Index & $\begin{array}{l}-0.156^{* * *} \\
(-3.27)\end{array}$ & $\begin{array}{l}-0.066^{*} \\
(-2.13)\end{array}$ & $\begin{array}{l}-0.138 * * * \\
(-3.04)\end{array}$ & $\begin{array}{l}-0.086^{*} \\
(-2.12)\end{array}$ \\
\hline Big_4 & $\begin{array}{l}-0.029 \\
(-1.26)\end{array}$ & $\begin{array}{l}-0.016 \\
(-0.69)\end{array}$ & $\begin{array}{l}-0.025 \\
(-1.16)\end{array}$ & $\begin{array}{l}-0.015 \\
(-0.78)\end{array}$ \\
\hline Log_ASSET & $\begin{array}{l}-0.024 * * \\
(-1.37)\end{array}$ & $\begin{array}{l}-0.022 * \\
(-1.33)\end{array}$ & $\begin{array}{l}-0.037 * * \\
(-2.19)\end{array}$ & $\begin{array}{l}-0.031 * * \\
(-2.05)\end{array}$ \\
\hline Debt & $\begin{array}{l}0.316^{* * * *} \\
(2.37)\end{array}$ & $\begin{array}{l}0.315^{* *} \\
(2.59)\end{array}$ & $\begin{array}{l}0.266^{* * * *} \\
(2.10)\end{array}$ & $\begin{array}{l}0.270^{* * * *} \\
(2.39)\end{array}$ \\
\hline ROA & $\begin{array}{l}0.043^{* *} \\
(2.45)\end{array}$ & $\begin{array}{l}0.037 * * \\
(2.21)\end{array}$ & $\begin{array}{l}0.052^{* * * *} \\
(3.14)\end{array}$ & $\begin{array}{l}0.044 * * * \\
(2.99)\end{array}$ \\
\hline GROWTH & $\begin{array}{l}0.029 * * * \\
(3.27)\end{array}$ & $\begin{array}{l}0.025^{* * * *} \\
(3.29)\end{array}$ & $\begin{array}{l}0.019 * * \\
(2.24)\end{array}$ & $\begin{array}{l}0.014^{*} \\
(1.88)\end{array}$ \\
\hline Loss & $\begin{array}{l}0.006 \\
(0.22)\end{array}$ & $\begin{array}{l}0.012 \\
(0.49)\end{array}$ & $\begin{array}{l}0.011 \\
(0.42)\end{array}$ & $\begin{array}{l}0.005 \\
(0.19)\end{array}$ \\
\hline Significance & 0.000 & 0.000 & 0.000 & 0.000 \\
\hline Adjusted $R^{2}$ & 0.2777 & 0.2255 & 0.2306 & 0.2687 \\
\hline Number of Observations & 1,740 & 1,740 & 1,740 & 1,740 \\
\hline
\end{tabular}

Notes. The model includes industry sectors and time controls, but they are not reported. $Z$ statistics in parentheses

Quantitative variables: Int_OWN Internal ownership, measured by the proportion of shares owned by managers and members of Boards ( $\geq 1 \%)$; OWN_Con Ownership Concentration, measured by the ratio of shares held by the major shareholder of the company ( $\geq 5 \%)$; Fam_OWN Family Ownership, measured by the proportion of shares held by family members $(\geq 5 \%)$, as a percentage of capital that is directly or indirectly in his possession; Inst_OWN Institutional Ownership, measured by the proportion of shares held by institutional investors; Board_SIZE Size of boards of directors, measured by the total number of members of Boards; Board_IND independence of the Board, measured by the proportion of independent members (independent directors/total directors); Board_ACT Activity of Boards, measured by the number of meetings; Log_ASSET Firm size, measured by the natural logarithm of total assets of the companies; Debt Level of indebtedness, measured by the quotient resulting from gross debt to total assets, ROA Economic Return, measured by the ratio of the relation between the result before special items, interest and taxes of year $t$ and the total net assets at the beginning of year $t$; GROWTH Growth of the Companies, calculated in terms of the ratio of the difference in sales and sales of the previous period of firm $i$ in year $t$; GOV_Index The degree of law enforcement of each country analyzed, taken from the research project "Worldwide Governance Indicators" (WGI) proposed by Kaufmann et al. (2010)

Dichotomous variables: Boad_IND50 Measured through a dummy variable that takes value of 1 if boards has a majority of independent directors and, 0 otherwise; $C E O \_D u a l$ Measured through a dummy variable that considers the value of 1 if there is duality of roles between the chairman and CEO of the companies and, 0 otherwise; Big_4 Measured by a dummy variable that takes the value 1 if the firms are audited by one of the big four firms, 0 otherwise; Loss Measured through a dummy variable that takes value of 1 if the companies have had losses in the last 2 years and, 0 otherwise

*** Significant at level $1 \%$, ** significant at level $5 \%$, significant at level $10 \%$ 
effectiveness of government, this seems to influence EM negatively, i.e., it shows an increase in the quality and transparency of the financial information issued by companies, thus showing a reduction of discretionary accruals. The results are in line with those noted by Labelle et al. (2010), who point to a higher level of corporate moral development being associated with higher quality financial reporting.

Our research contributes to the debate by demonstrating that, in Latin America, with a corporate governance system characterized by low investor protection and high ownership concentration, insider ownership and ownership concentration affect discretionary accruals. The findings demonstrate that on average earnings are more likely to be manipulated when insider ownership and ownership concentration is too high. Both results are consistent with insiders and large shareholders possessing information acquisition and information processing advantages. This study also has policy implications by showing that corruption, inefficiency of governments and a weak rule of law increase opportunistic behavior in Latin American firms. Our findings also have important policy implications since they support the opinion that the full application of the Anglo-Saxon corporate governance model is inappropriate (Sanchez-Ballesta and Garcia-Meca 2007) and they contribute to the literature by extending the research into the effects of corporate governance on portfolio firm's earnings management.

Our research design is subject to several limitations. The most obvious concern is the measurement problems of earnings management. Nevertheless, the different models used in the paper (Jones original, Jones modified, Jones cash flow, and KS model) indicate that the results are robust after controlling for alternative measures of discretionary accounting accruals. Because our results focus on four Latin American countries and on one period, 2006-2009, both country and time period are other limitations of the study. Further research might examine if the relations found in this study can be extended to other Latin American countries and periods. This could provide increased robustness of the results. A further refinement of the variables used (e.g., if in the future regulators forced companies to disclose whether the independent directors have any conflict of interest that would alter the degree of Board independence), or the simple fact of having data that it is currently difficult to know, such as the nationality of institutional investors, could lead to a better understanding of the relation between internal mechanism of CG and EM in Latin American markets. Despite these limitations, this study adds to the ethics literature by considering the ownership structure and board of directors and extends the line of research on earnings management and corporate governance.

\section{Concluding Remarks}

Being aware of the existence of opportunistic EM activities evokes a general interest in factors that may constrain these actions. The main objective was to analyze the relation between the internal mechanisms of CG and EM in firms listed on the main Latin American stock markets, specifically in the markets of Argentina, Brazil, Chile and Mexico, during the period 2006-2009. The findings offer new insights into these relations in an institutional context that greatly differs from those of the countries considered in previous literature (particularly the US system).

The findings show that the environment of high ownership concentration that exists in Latin American companies negatively affects the quality and transparency of financial information that is issued to the market, suggesting that ownership concentration may be a constrictor mechanism of manipulative practices only when the ownership of the main shareholders is moderate. Similarly, internal ownership is a mechanism that, despite differences in CG systems, could restrict the practices of discretionary accruals only when the proportion of shares owned by insiders is not very high.

In contrast to the Anglo-Saxon context, the relation found between the level of earnings manipulation and the proportion of independent directors is weak, probably due to the presence of grey directors and the lack of rotation of directors in Latin American firms.

Furthermore, our results show that when a country implements controls aimed at behaving ethically, reducing corruption, strengthen the rule of law or improving the effectiveness of government, these seem to increase the quality and transparency of the financial information issued by firms, so improving ethical behavior of their managers and, consequently, showing a reduction of discretionary accruals. As a result, this paper tries to provide valuable input for regulators who are requesting continuous analytical work to know the implications of exceptionally poor governance and it suggests that policy makers should consider the characteristics of firms as well as the institutional environment before they implement additional corporate governance reforms.

Acknowledgments This study is part of research project ECO201129144-C03-02, supported by the Ministry of Economic and Competitiveness of Spain.

Open Access This article is distributed under the terms of the Creative Commons Attribution License which permits any use, distribution, and reproduction in any medium, provided the original author(s) and the source are credited.

\section{Appendix}

See Table 9. 
Table 9 Correlation matrix

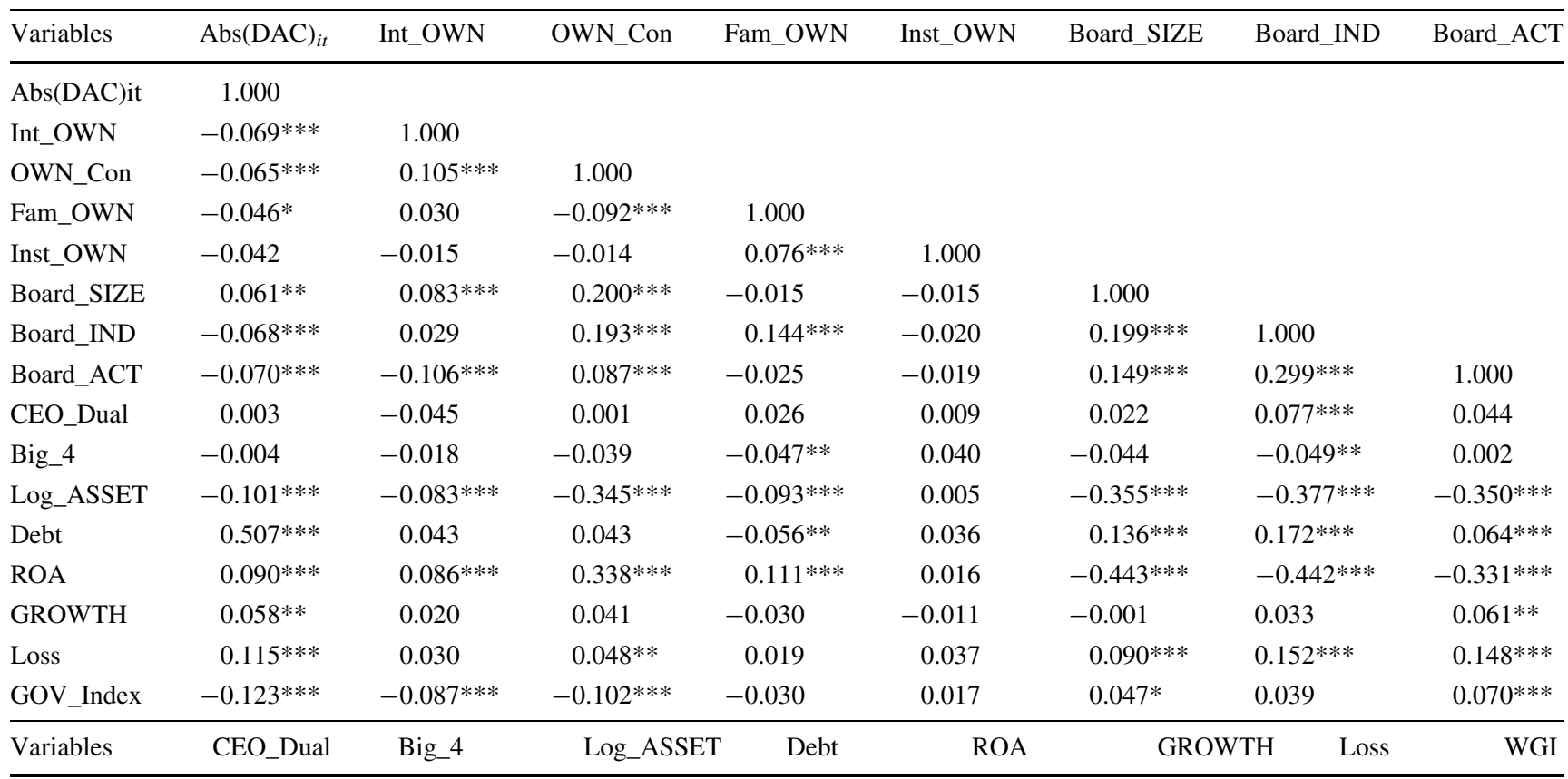

Abs(DAC)it

Int_OWN

OWN_Con

Fam_OWN

Inst_OWN

Board_SIZE

Board_IND

Board_ACT

CEO_Dual

Big_4

1.000

$0.057 * *$

1.000

Debt

$-0.059 * *$

$0.113 * * *$

1.000

ROA

0.020

$0.050 * *$

$-0.164 * * *$

1.000

GROWTH

$-0.065 * * *$

$0.118 * * *$

$0.274 * * *$

$-0.120 * * *$

1.000

Loss

$-0.022$

GOV_Index

$0.078 * * * \quad-0.036$

$-0.059 * *$

$-0.021$

$-0.050^{* *}$

1.000

$-0.226 * * *$

$0.213 * * *$

$-0.218 * * *$

$-0.057 * *$

1.000

0.001

$0.119 * * *$

$-0.073 * * * \quad-0.033$

$0.157 * * *$

1.000

Quantitative variables: $A b s(D A C)_{i t}$ Absolute value of discretionary accruals estimated from the Modified Jones Model; Int_OWN Internal ownership, measured by the proportion of shares owned by managers and members of Boards $(\geq 1 \%)$; OWN_Con Ownership Concentration, measured by the ratio of shares held by major shareholder of the company ( $\geq 5 \%)$; Fam_OWN Family Ownership, measured by the proportion of shares held by family members $(\geq 5 \%)$, as a percentage of capital that is directly or indirectly in his possession; Inst_OWN Institutional Ownership, measured by the proportion of shares held by institutional investors; Board_SIZE Size of boards of directors, measured by the total number of members of Boards; Board_IND independence of the Board, measured by the proportion of independent members (independent directors/total directors); Board_ACT Activity of Boards, measured by the number of meetings; Log_ASSET Firm size, measured by the natural logarithm of total assets of the companies; Debt Level of indebtedness, measured by the quotient resulting from gross debt to total assets, ROA Economic Return, measured by the ratio of the relation between the result before special items, interest and taxes of year $t$ and the total net assets at the beginning of year $t$; GROWTH Growth of the Companies, calculated in terms of the ratio of the difference in sales and sales of the previous period of firm $i$ in year $t$; GOV_Index The degree of law enforcement of each country analyzed, taken from the research project "Worldwide Governance Indicators" (WGI) proposed by Kaufmann et al. (2010)

Dichotomous variables: Boad_IND50 Measured through a dummy variable that takes value of 1 if boards has a majority of independent directors and, 0 otherwise; CEO_Dual Measured through a dummy variable that considers the value of 1 if there is duality of roles between the chairman and CEO of the companies and, 0 otherwise; Big_4 Measured by a dummy variable that takes the value 1 if the firms are audited by one of the big four firms, 0 otherwise; Loss Measured through a dummy variable that takes value of 1 if the companies have had losses in the last 2 years and, 0 otherwise

$* * *$ Significant at level $p \leq 0.01, * *$ significant at level $p \leq 0.05$, * significant at level $p \leq 0.10$ 


\section{References}

Aboody, D., \& Kaznik, R. (2000). CEO stock option awards and the timing of corporate voluntary disclosures. Journal of Accounting and Economics, 29, 73-100.

Adams, R. (2003). What do Boards do? Evidence from Board Committee and Director Compensation data. Working Paper, University of Queensland.

Aidt, T. (2009). Corruption, institutions, and economic development. Oxford Review of Economic Policy, 25(2), 271-291.

Ali, A., Chen, T., \& Radhakrishnan, S. (2007). Corporate disclosures by family firms. Journal of Accounting and Economics, 44, 238-286.

Alonso, S., \& De Andrés, P. (2002). Estructura de propiedad y resultados en la gran empresa española. Evidencia empírica en el contexto de una relación endógena. XII Congreso Nacional de ACEDE, Palma de Mallorca.

Anderson, R., \& Reeb, D. (2003). Founding-family ownership and firm performance: Evidence from the S\&P 500. Journal of Finance, 58, 1301-1328.

Anokhin, S., \& Schulze, W. (2008). Entrepreneurship, innovation and corruption. Journal of Business Venturing, 18(4), 473-490.

Arellano, M. (1993). Introducción al análisis econométrico con datos de panel. La industria y el comportamiento de las empresas españolas. Ensayos en homenaje a Gonzalo Mato, Alianza Editorial, Madrid, pp. 23-47.

Arellano, M., \& Bover, A. (1991). La econometría de datos de panel. Investigaciones Económicas, 14(1), 3-45.

Azofra, V., De Andrés, P., \& Lopez, S. (2005). Corporate Boards in OECD countries: Size, composition, functioning and effectiveness. Corporate Governance: An International Review, 13(2), 197-210.

Balsam, S., Chen, H., \& Sankaraguruswamy, S. (2003). Earnings management prior to stock option grants. Working Paper SSRN.

Baltagi, B., \& Chang, Y. (1994). Incomplete panels: A comparative study of alternative estimators for the unbalanced one way error component regression model. Journal of Econometrics, 62, 67-89.

Barth, M., Landsman, W., \& Lang, M. (2008). International accounting standards and accounting quality. Journal of Accounting Research, 46(3), 467.

Bona, C., Perez, J., \& Santana, D. (2008). Family control and earnings management. $R C$-SAR, 10(1), 11-34.

Boubraki, N., Cosset, J., \& Guedhami, O. (2005). Post-privatization corporate governance: The role of ownership structure and investor protection. Journal of Financial Economics, 76(2), 369-399.

Bradbury, M., Mak, Y., \& Tan, S. (2006). Board characteristics, audit committee characteristics, and abnormal accruals. Pacific Accounting Review, 18, 47-68.

Brick, I., Palia, D., \& Wang, C. (2005). Simultaneous estimation of CEO compensation, leverage, and board characteristics on firm value. Working Paper SSRN

Brick, I., Palmon, O., \& Wald, J. (2006). CEO compensation, director compensation, and firm performance: Evidence of cronyism. Journal of Corporate Finance, 12, 403-423.

Castañeda, G. (2000a). Internal capital markets and financial crisis: An explanation of the Mexican recovery after the 1995 crisis. Working Paper.

Castañeda, G. (2000b). Governance of large corporations in Mexico and productivity implications. Revista Abante, 3(1), 57-89.

Castrillo, L., \& San Martín, R. (2007). La propiedad familiar como mecanismo de gobierno disciplinador de la dirección en las empresas mexicanas: una evidencia empírica. Contaduría y Administración, 222, 59-82.
Cespedes, J., Gonzalez, M., \& Molina, C. (2008). Ownership concentration and determinants of capital structure in Latin America. Working Paper.

Chatterjee, S., Harrison, J., \& Bergh, D. (2003). Failed takeover attempts, corporate governance and refocusing. Strategic Management Journal, 24, 87-96.

Chen, C., \& Jaggi, B. (2000). Association between non-executives directors, family control and financial disclosures in Hong Kong. Journal of Accounting and Public Policy, 9(4-5), 285-310.

Chen, K., Randal, J., \& Yung-Ming, H. (2007). Corporate governance and earnings management: the implications of Corporate Governance Best Practice Principles for Taiwanese listed companies. Working Paper National Cheng Kung University.

Cheng, E., \& Courtenay, S. (2006). Board composition, regulatory regime and voluntary disclosure. International Journal of Accounting, 41, 262-289.

Chin, K., Firth, M., \& Kim, J. (2006). Earnings management, corporate governance, and the market performance of seasoned equity offerings. Journal of Contemporary Accounting and Economics, 36, 73-98.

Chisari, O., \& Ferro, G. (2009). Corporate governance: The problems, the current stage of the discussion and measurement exercise for Argentina. Working Paper, Munich Personal RePEc Archive (MPRA)

Chong, A., Guillen, J., \& Lopez de Silane, F. (2009). Corporate governance reform and firm value in México: An empirical assessment. Journal of Economic Policy Reform, 12(3), $163-168$.

Chung, R., Firth, M., \& Kim, J. (2002). Institutional monitoring and opportunistic earnings management. Journal of Corporate Finance, 8, 29-48.

Core, J., Holthausen, R., \& Larcker, D. (1999). Corporate governance, chief executive officer compensation, and firm performance. Journal of Financial Economics, 51, 371-406.

Cornett, M., Marcus, A., Saunders, A., \& Tehranian, H. (2008). Corporate governance and pay for performance: The impact of earnings management. Journal of Financial Economics, 87, 357-373.

Daily, C., Dalton, D., \& Cannella, A. (2003). Corporate governance: Decades of dialogue and data. Academy of Management Review, $28,371-382$.

Davidson, R., Goodwin, J., \& Kent, P. (2005). Internal governance structures and earnings management. Accounting and Finance, $45,241-267$.

Davila, M., \& Watkins, K. (2009). Corporate Governance and Turnovers in México. Working Paper, Universidad Popular Autónoma de Puebla, pp. 1-34.

De Andrade, L., Torres, G., \& Leal, C. (2009). Governança Corporativa: Uma análise da relação do Conselho de Administração com o valor de mercado e desempenho das empresas brasileiras. Revista de Administração Mackenzie, 10(4), 4-31.

De Bos, A., \& Donker, H. (2004). Monitoring accounting changes: Empirical evidence from Netherlands. Corporate Governance, 12(1), 60-73.

De Miguel, A., Pindado, J., \& De la Torre, C. (2004). Ownership structure and firm value: new evidence from Spain. Strategic Management Journal, 25, 1199-1207.

Dechow, P., \& Schrand, C. (2004). Earnings quality. New York: The Research Foundation of CFA Institute.

Dechow, P., Sloan, R., \& Sweeney, A. (1995). Detecting earnings management. The Accounting Review, 70, 193-225.

DeFond, M., \& Jiambalvo, J. (1991). Incidence and circumstances of accounting errors. The Accounting Review, 66, 643-655.

DeFond, M., \& Subramanyam, K. (1998). Auditor changes and discretionary accruals. Journal of Accounting and Economics, $25,35-67$. 
Dela Rama, M. (2011). Corporate governance and corruption: Ethical dilemmas of Asian business groups. Journal of Business Ethics, 109, 501-519.

Demsetz, H., \& Villalonga, B. (2001). Ownership structure and corporate performance. Journal of Corporate Finance, 7, 209-233.

Eguidazu, S. (1999). Creación de valor y gobierno de la empresa en España. Madrid: Morgan Stanley Dean Witter.

Fama, E. (1980). Agency problems and theory of the firm. The Journal of Political Economy, 88(2), 288-307.

Fama, E., \& Jensen, M. C. (1983). Separation of ownership and control. Journal of Law and Economics, 26(2), 301-325.

Fernandez, A. (1998). El gobierno corporativo: la supervisión y control de las actuaciones gerenciales. Economía Aragonesa, publicación trimestral de la Caja de Ahorros y Monte de Piedad Zaragoza, Aragón y Rioja, 5, 111-128.

Fernandez, A., Gomez, S., \& Fernandez, C. (1997). The effect of board size and composition on corporate performance. In M. Balling, et al. (Eds.), Corporate governance, financial markets and global convergence. Boston: Kluwer Academic Publishers.

Ferraz, L., Fernandez, H., \& Louvel, P. (2011). Um índice de avaliação da qualidade da governança corporativa no Brasil. $R$. Cont. Fin. - USP, São Paulo, 22(55), 45-63.

Ferreira, M., Massa, M., \& Matos, P. (2010). Shareholders at the gate? Institutional investors and cross-border mergers and acquisitions. The Review of Financial Studies, 23(2), 601-644.

Ferreira, M., \& Matos, P. (2008). The colors of investor's Money: The role of institutional investors around the world. Journal of Financial Economics, 88, 499-533.

Francis, J., \& Wang, D. (2004). Investor protection, auditor conservatism and earnings quality: Are Big 4 auditors conservative only in the United States? Working Paper, University of Missouri-Columbia.

Gabrielsen, G., Jeffrey, D., \& Thomas, P. (2002). Managerial ownership, information content of earnings, and discretionary accruals in a non-US setting. Journal of Business Finance \& Accounting, 29, 967-988.

Galang, R. (2011). Victim or victimizer: Firm responses to government corruption. Journal of Management Studies. doi:10.1111/ j.1467-6486.2010.00989.x.

Garcia Lara, J., Garcia Osma, B., \& Peñalva, F. (2009). Accounting conservatism and corporate governance. Review of Accounting Studies, 14(1), 161-201.

García Osma, B., \& Gill de Albornoz, B. (2007). The effect of the board composition and its monitoring committees on earnings management: Evidence from Spain. Corporate Governance: An International Review, 15(6), 1413-1428.

Gill, I., \& Kharas, H. (2007). An East Asian renaissance: Ideas for economic growth. Washington, DC: World Bank Group.

Goodwin, J., \& Kent, P. (2006). Relation between external audit fees, audit committee characteristics and internal audit. Accounting and Finance, 46, 387-404.

Hashim, H. A., \& Devi, S. S. (2008). Board Independence, CEO duality and accrual management Malaysian evidence. Asian Journal of Business and Accounting, 1(1), 27-46.

Hausman, J. (1978). Specification tests in econometrics. Econometrica, 46, 1251-1271.

Healy, P. (1985). The effect of bonus schemes on accounting decisions. Journal of Accounting and Economics, 7(1-3), 83-107.

Helland, E., \& Sykuta, M. (2005). Who's monitoring the monitor? Do outside directors protect share holders' interest? The Financial Review, 40(2), 155-172.

Himmelberg, C., Hubbard, R., \& Palia, D. (1999). Understanding the determinants of managerial ownership and the link between ownership and performance. Journal of Financial Economics, 53, 353-384.

Holthausen, R., Larcker, D., \& Sloan, R. (1995). Annual bonus schemes and the manipulation of earnings. Journal of Accounting and Economics, 19, 29-74.

Hoshino, T. (2004). Family Business in Mexico: Response to human resources limitations and management succession, The Institute of Developing Economies, Discussion Paper 12.

Hsu, G., \& Koh, P. (2005). Does the presence of institutional investors influence accruals management? Evidence from Australia. Corporate Governance, 13(6), 809-823.

Husted, B., \& Serrano, C. (2002). Corporate governance in Mexico. Journal of Business Ethics, 37(3), 337-348.

Iglesias, A. (1999). Economic impact of pension reforms in Chile, Mimeo.

Iglesias, A. (2000). The impact of pension reform on corporate governance practices and regulations: Evidence from Chile. Revista Abante, 3(1), 5-28.

Jaggi, B., Leung, S., \& Gul, F. (2009). Family control, board independence and earnings management: Evidence based on Hong Kong firms. Journal of Accounting and Public Policy, 28(4), 281-298.

Jara, M., \& López, F. (2007). Auditoría y discrecionalidad contable en La gran empresa no financiera española. Revista Española de Financiación y Contabilidad, 135, 569-594.

Jensen, M., \& Meckling, W. (1976). Theory of the firm: Managerial behavior, agency costs and ownership structure. Journal of Financial Economics, 3(4), 305-360.

Jeter, D., \& Shivakumar, L. (1999). Cross sectional estimation of abnormal accruals using quarterly and annual data: Effectiveness in detecting event specific earnings management. Accounting Business Research, 29, 193-228.

John, K., \& Senbet, L. (1998). Corporate governance and board effectiveness. Journal of Banking \& Finance, 22, 371-403.

Jones, J. (1991). Earnings management during import relief investigations. Journal of Accounting Research, 29(2), 193-228.

Kang, S., \& Sivaramakrishnan, K. (1995). Issues in testing earnings management and an instrumental variable approach. Journal Accounting Research, 33(2), 355-367.

Karamanou, I., \& Vafeas, N. (2005). The association between corporate boards, audit committees, and management earnings forecast: An empirical analysis. Journal of Accounting Research, 43(3), 453-486.

Kaufmann, D., Kraay, A., \& Mastruzzi, M. (2010). The worldwide governance indicators: A summary of methodology, data and analytical issues. World Bank Policy Research. Working Paper 5430. http://papers.ssrn.com/sol3/papers.cfm?abstract_id=1682130.

Kim, J., \& Yi, C. (2006). Ownership structure, business group affiliation, listing status and earnings management: Evidence from Korea. Contemporary Accounting Research, 23(2), 427-464.

Koh, P. (2003). On the association between institutional ownership and aggressive corporate earnings management in Australia. British Accounting Review, 35, 105-128.

Kothari, S., Leone, A., \& Wasley, C. (2005). Performance matched discretionary accrual measures. Journal of Accounting and Economics, 39(1), 163-197.

Krishnan, J., Krishnan, J., \& Stephen, R. (1996). The simultaneous relation between auditor switching and audit opinion: An empirical analysis. Accounting and Business Research, 26(3), 136-224.

La Porta, R., Lopez de Silanes, F., Shleifer, A., \& Vishny, R. (1999). Corporate governance around the world. The Journal of Finance, 54, 471-517. 
Labelle, R., Gargouri, R. M., \& Francoeur, C. (2010). Ethics, diversity management and financial reporting quality. Journal of Business Ethics, 93, 335-353.

LaFond, R., \& Roychowdhury, S. (2006). The implications of Agency Problems between managers and shareholders for the relation between managerial ownership and accounting conservatism. Working Paper SSRN.

Lang, M., \& Lundholm, R. (2000). Voluntary disclosure and equity offerings: Reducing information asymmetry or hyping the stock. Contemporary Accounting Research, 17(4), 623-669.

Leal, R., \& Carvalhal da Silva, A. (2005). Corporate governance and value in Brazil, IDB Draft Paper.

Lefort, F. (2005). Ownership structure and corporate governance in Latin America. Revista Abante, 8(1), 55-84.

Lefort, F. (2007). Corporate governance in Latin America. In A. Chong \& F. Lopez de Silane (Eds.), Investor protection and corporate governance firm level evidence across Latin America. Washington, DC: Stanford University Press.

Lefort, F. \& Walker, E. (2005). The effect of corporate governance practices on company market valuation and payout policy in Chile. Working Paper, R-515, Inter-American Development Bank, Latin American Research Network.

Lennox, C. (1999). Are large auditors more accurate than small auditors? Accounting and Business Research, 29(3), 217-227.

Leuz, C., Nanda, D., \& Wysocki, P. (2003). Earnings management and investor protection: An international comparison. Journal of Financial Economics, 69(3), 505-527.

Lopez, F., \& Saona, P. (2005). Earnings management and internal mechanisms of corporate governance: Empirical evidence from Chilean firms. Corporate Ownership \& Control, 3(1), 16-29.

Lorca, C., Sanchez-Ballesta, J., \& Garcia-Meca, E. (2011). Board effectiveness and cost of debt. Journal of Business Ethics, 100, 613-631.

Machuga, S., \& Teitel, K. (2007). The effects of the Mexican Corporate Governance Code on quality of earnings and its components. Journal of International Accounting Research, 6(1), 37-55.

Machuga, S., \& Teitel, K. (2009). Board of director's characteristics and earnings quality surrounding implementation of a corporate governance code in Mexico. Journal of International Accounting, Auditing and Taxation, 18(1), 45-74.

Manzetti, L., \& Wilson, C. (2007). Why do corrupt governments maintain public support? Comparative Political Studies, 40(8), 949-970.

Matis, D., Vladu, A., Negrea, L., \& Sucala, L. (2010). Jones, Dechow and Kasznik models significance in Romanian economic environment. Annuale Universitatis Apulensis Series Oeconomica, 12(1), 253-266.

McNichols, M. (2000). Research design issues in earnings management studies. Journal of Accounting and Public Policy, 19(4-5), $313-345$

Mcvey, H., \& Draho, J. (2005). U.S. family run companies: They maybe better than you think. Journal of Applied Corporate Finance, 17(4), 134-143.

Mehran, H. (1995). Executive compensation structure, ownership and firm performance. Journal of Financial Economics, 38, 163-184.

Mendes, D., \& Mazzer, R. (2005). Estrutura de propriedade e de controle das empresas de capital aberto no Brasil. Revista de Economia Política, 25(2), 115-137.

Menon, K., \& Williams, J. (1994). The use of Audit Committee for monitoring. Journal of Accounting and Public Policy, 13(2), 121-139.

Monterrey, J., \& Sánchez, A. (2008). Gobierno Corporativo, conflictos de agencia y elección de auditor. Revistas Española de Financiación y Contabilidad, 38(107), 113-156.
Morck, R., Shleifer, A., \& Vishny, R. (1988). Management ownership and market valuation: An empirical analysis. Journal of Financial Economics, 20, 293-315.

Nurul, M., Dunstan, K., Waresul, A., \& Van Zijl, T. (2010). Board ethics and auditor choice: International evidence. Working Paper, Centre for Accounting, Governance and Taxation Research.

Palia, D. (2001). The endogeneity of managerial compensation in firm valuation, a solution. The Review of Financial Studies, 14(3), 735-764.

Patelli, L., \& Prencipe, A. (2007). The relationship between voluntary disclosure and independent directors in the presence of a dominant shareholder. European Accounting Review, 16, 5-33.

Pearce, J., \& Zahra, S. (1992). Board composition from a strategic contingency perspective. Journal of Management Studies, 29, 411-438.

Press, E., \& Weintrop, J. (1990). Accounting based constraints in public and private debt agreements: Their association with leverage and impact on accounting choice. Journal of Accounting and Economics, 12(1-3), 65-95.

Price, R., Roman, F., \& Rountree, B. (2006). Governance reform, share concentration and financial reporting transparency in Mexico. SSRN Working Paper, Rice University.

Prior, D., Surroca, J., \& Tribo, J. (2008). Are socially responsible managers really ethical? Exploring the relationship between earnings management and corporate social responsibility. Corporate Governance, 16(3), 160-177.

Rabelo, F., \& Coutinho, L. (2001). Corporate governance in Brazil. OECD Development Centre.

Rahman, R., \& Ali, F. (2006). Board, audit committee, culture and earnings management: Malaysian evidence. Managerial Auditing Journal, 21(7), 783.

Rajgopal, S., Venkatachalam, M., \& Jiambalvo, J. (2002). Is institutional ownership associated with earnings management and extend to which stock prices reflect future earnings? Contemporary Accounting Research, 19, 117-136.

Rose-Ackerman, S. (2001). Trust, honesty and corruption: Reflection of the state building process. European Journal Social, 42, $27-71$.

Roychowdhury, S. (2006). Management of earnings through the manipulation of real activities that affect cash flow from operations. Journal of Accounting and Economics, 42, 335-370.

Ruiz, M., Pérez, J., Bona, C., \& Santana, D. (2009). Calidad Del resultado y propiedad institucional. Working Paper, Universidad de las Palmas de Gran Canaria, pp. 323-339.

Ruiz-Porras, A., \& Steinwascher, W. (2007). Gobierno corporativo, diversificación estratégica y desempeño empresarial en México. Working Paper 2007/03, Tecnológico de Monterrey.

Sacristan, M., \& Gomez, S. (2007). Family ownership and pyramids in the Spanish market. Family Business Review, 20(3), 247-265.

Sanchez, A., \& Sierra, G. (2001). Informe de auditoría y su relación con las características corporativas. Revista Española de Financiación y Contabilidad, 30(108), 349-391.

Sanchez-Ballesta, J., \& Garcia-Meca, E. (2007). Ownership structure, discretionary accruals and the informativeness of earnings. Corporate Governance: An International Review, 15, 677-691.

Santiago, M., \& Baek, H. (2003). Board composition and firm performance of large Latin American firms: An exploratory view. Latin American Business Review, 4, 1-19.

Santiago, M., \& Brown, C. (2009). An empirical analysis of Latin American board of directors and minority shareholders' rights. Forum Empresarial, 14(2), 1-18.

Santiago, M., Brown, C., \& Baez, A. (2009). Prácticas de gobierno corporativo en América Latina. Academia Revista Latinoamericana de Administración, 43, 26-40. 
Schiehll, E., \& Santos, I. (2004). Ownership structure and composition of boards of directors: Evidence on Brazilian publiclytraded companies. Revista de Administração, 39(4), 373-384.

Shleifer, A., \& Vishny, R. (1993). Corruption. The Quarterly Journal of Economics, 108(3), 599-617.

Shleifer, A., \& Vishny, R. (1997). A survey of corporate governance. The Journal of Finance, 52(2), 737-783.

Silveira, A., Barros, L., \& Fama, R. (2003). Estrutura de governança e valor das companhias abertas brasileiras. Revista de Administração de Empresas, 43(3), 50-64.

Teitel, K., \& Machuga, S. (2008). The complementary/substitution effects of the Code of Best Practices in Mexico with firm specific characteristics on the improvement in the quality of earnings. SSRN Working Paper.

Teoh, S., Welch, I., \& Wong, T. (1998). Earnings management and the underperformance of seasoned equity offerings. Journal of Financial Economics, 50, 63-99.

Teshima, N., \& Shuto, A. (2008). Managerial ownership and earnings management: Theory and empirical evidence from Japan. Journal of International Financial Management and Accounting, 19(2), 107-132.

Thomsen, S. (2008). A minimum theory of boards. International Journal of Corporate Governance, 1(1), 73-96.

Vafeas, N. (1999). Board meeting frequency and firm performance. Journal of Financial Economics, 53(113), 142.

Velury, U., \& Jenkins, D. (2006). Institutional ownership and the quality of earnings. Journal of Business Research, 59(9), $1043-1051$.

Voliotis, S. (2011). Abuse of ministerial authority, systemic perjury, and obstruction of justice: Corruption in the shadows of organizational practice. Journal of Business Ethics, 102(4), $537-562$.

Wang, D. (2006). Founding family ownership and earnings quality. Journal of Accounting Research, 44(3), 619-656.

Wartfield, T., Wild, J., \& Wild, K. (1995). Managerial ownership, accounting choices, and informativeness of earnings. Journal of Accounting and Economics, 20(1), 61-91.

Weisbach, M. (1988). Outside directors and CEO turnover. Journal of Financial Economics, 20, 431-460.

Willekens, M., Bauwhede, H., Gaeremynck, A., \& Van De Gucht, L. (2005). Internal and external governance and the unitary disclosure of financial and non financial performance. Working Paper SSRN.

Xie, B., Davidson, W., I. I. I., \& Dadalt, P. (2003). Earnings management and corporate governance: The roles of the board and the audit committee. Journal of Corporate Finance, 9(3), 295-316.

Yeo, G., Tan, P., Ho, K., \& Chen, S. (2002). Corporate ownership structure and the informativeness of earnings. Journal of Business Finance and Accounting, 29(7), 1022-1046.

Yermack, D. (1997). Good timing: CEO stock option awards and company news announcements. Journal of Finance, 52, 449-476.

Yermack, D. (2004). Remuneration, retention and reputation incentives for outside directors. Journal of Finance, 59, 2281-2308.

Zattoni, A., \& Cuomo, F. (2010). How independent, competent and incentivized should non-executive directors be? An empirical investigation of good governance codes. British Journal of Management, 21, 63-79. 